\title{
The Significance of
}

\section{Heredity and the Neuro-Insane Constitution}

AS

Impoptant Factors in the Produetion of Mental Disease;

WITH AN

Examination into the History of 100 Consecutive Cases.

By

G. RUTHERFORD JEFFREY,

M.B., Ch.B. (Glasg.), M.R.C.P. (E.din.),

Senior Assistant Physician, Crichton Royal Institution, Dumfries.

Late Senior Assistant Physician, District Asylum, Ayr. 
ProQuest Number: 27626768

All rights reserved

INFORMATION TO ALL USERS

The quality of this reproduction is dependent upon the quality of the copy submitted.

In the unlikely event that the author did not send a complete manuscript and there are missing pages, these will be noted. Also, if material had to be removed, a note will indicate the deletion.

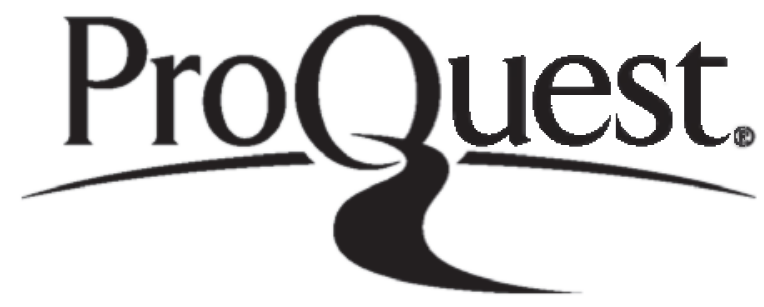

ProQuest 27626768

Published by ProQuest LLC (2019). Copyright of the Dissertation is held by the Author.

All rights reserved.

This work is protected against unauthorized copying under Title 17, United States Code Microform Edition (C) ProQuest LLC.

ProQuest LLC.

789 East Eisenhower Parkway

P.O. Box 1346

Ann Arbor, Ml $48106-1346$ 


\section{The Significance of Heredity and the Neuro-Insane Constitution as} Important Factors in the Production of Mental Disease. .

迹

OM the earliest times in the history of medicine, probably no subject has been more thought about, no subject more frequently attacked than that of Heredity, and it is therefore not without a certain amount of hesitation that that all-important subject is brought into consideration in such an article as this.

At the very commencement of the study of medicine; the attention of the student is soon directed towards Heredity, although it is not to the student of medicine alone that this subject is of interest. To the every-day individual, layman and professional man alike, it is a subject that is constantly demanding attention. In the animal kingdom its importance seems never for a moment to be doubted, whilst in the breeding of animals its significance stands unchallenged. For example, by careful selection and mating of animals, special breeds are procured-in horses, speed, endurance, and strength can be obtained; in cattle the size and dairy qualities of the animal; in sheep the quality of the wool-these being only a few examples of what can be attained by taking into consideration the parentage, or, in other words, recognising the importance of heredity.

Among the ancients, the principles of heredity must have been recognised and undoubtedly gave rise to certain family names among the Romans, as e.g., the Nasones, Capitones, etc., whilst, coming to more recent times, such an expression as the "Bourbon Nose," is sufficient to show that it is a characteristic which has been handed down from one generation to another.

In the diseases to which the human frame is subjected, the problem of heredity is never neglected. By some its significance is accepted, and is held thereby to explain a condition that is quite beyond ordinary understanding.

As years have advanced, the importance of Heredity in the production of certain diseases has received more special attention; facts have been established, and by soma accepted, and when one comes to the study of Psychological Medicine-probably the most intricate of all medical subjects-its significance has been accepted without perhaps sufficient grounds.

To a disease like Insanity, which at every corner is beset with appalling difficulties, Heredity is by some held to be the omnipotent factor in its production, whilst by others it is considered and set aside without sufficient thought. During the present time, when the "toxic theory" of Insanity is so much on the ascendant, the importance of Heredity is apt, by the younger generation at least, to be overlooked, and indeed anyone who tries to unravel its mystery and give to it its proper place, is by some said to be behind the times, is accused of being unscientific, and is thought thereby to have drifted back to the position 
of our ancestors, who not only did not know of such a thing as " microbic infection," but who firmly believed that many obscure diseases were directly transmitted from parent to offspring.

When one comes to consider the question of Insanity, there are facts about Heredity that cannot be passed unnoticed, there are facts which cannot be disputed, and yet no one would go the length of saying definitely that Insanity is a disease which is transmitted directly from parent to offspring. That in a large percentage of cases of Insanity occurring in an offspring, the disease can be traced in the family history is beyond doubt, and, as the tubercular parent may beget a child predisposed to the tubercular virus, so also the insane parent begets a child predisposed to Insanity - the most calamitous of all diseases. To say, however, that the parental germ cell is infected-- a condition at one time believed in-is making a statement which in the present state of our knowledge is scarcely justifiable. Notwithstanding, even this assumption requires reservation, for one is at once confronted with a condition like Hereditary Syphilis. In this the morbid poison is transmitted, but can it be proved that the infection took place through the actual parental germ cell?

No matter what statements are made, or what examples are given, for or against the inheritance of disease, we are bound in the first place to believe and accept as a fact that what we are as human bcings is largely, if not solely, the result of our inheritance. Is it not by inheritance that we human bcings belong to that marvellous genus-Man?

No one doubts the fact that one animal begcts its like-and its like only. Not only this, but the offspring boars in many cases a striking resemblance to the parent. Individual bodily conditions are reproduced, and more, individuality of character both good and bad appear in successive generations. The ovum enters upon its life so to speak charged with inheritance, and more, charged with an inheritance which in many cases cannot be passed over. In the face of facts such as these, one cannot for a moment doubt that an "unstable" parent is more likely to produce an unstable child than the reverse. Fortunately, however, this is not always so. We have always to consider the opposing factor, and remember that it may be the stronger. Were it not for this, the world would rapilly become filled with weaklings-- the offspring charged with unstable germ cells from say the father, is equally charged in the reverse way through the mother-and the sum total of those two individuals is in all probability an individual with the good and bad of both parents, but with those qualities probably much exaggerated, minimised, or equalised. If this be so, in the ordinary individuat, why not in the "afflicterl" one? Are we not bound to believe and accept the fact that in certain discases - chief of which is Insanity-the unhealthy parent must beget a child at all events predisposed to that disease?

We are led therefore to consider the "predisposition," and it is to this point that I wish to draw special attention in this paper. I do not wish to theorise on a subject like Heredity - far be it from me to even attempt without an apology to touch the fringes of such a subject, a subject which has occupied the attention of scientists for generations, and which, moreover, has baffled most; but I wish to draw attention to the importance of certain 
points as being of paramount interest and significance in the production of mental disease. For some knowledge of such a difficult and interesting subject as Heredity, the able works of such men as Darwin and Weismann must be consulted. It is interesting, however, to refer very brieny to the main points in the teaching of those two authors. Darwin in his book on the "Origin of Species" seems to indicate that, while the qualities and characters of the ancestors are transmitted to the offspring, there are circumstances, as, c.g., environment and example, which tend to modify or alter those qualitics, and more, that those qualicies or characters are gradually altered, inasmuch as their alteration is neccssary for the preservation of the species; in other words, qualities which will be useful in the. struggle for existence and in order that the fittest may survive. According to Weismann's conception, living matter has no ending. He believes in a "continuity of the germ plasm." "A part of the germ plasm contained in the parent egcr cell is not used up in the construction of the body of the offspring, but is reserved unchanged for the formation of the germ cells of the following generation. Thus the parent is rather the trustee of the grerm plasm than the producer of the child; and in a new sense the child is a chip of the old block. Similar material to start with, similar conditions in which to develop, therefore like tends to beget like." I

I shall at once, therefore, commence to draw attention to certain points in the production of mental disease points which are of importance because their position has been established by facts, and by facts which have been carefully and accurately elucidated.

The points which I propose to consider are:-

1st. The importance of, and the position held by, Heredity in Mental Diseases.

2nd. The importance and significance of the so-called Neuro-insane Constitution in people, the subjects of Mental Disease. And

3rd. The presence of a direct cause which is held to be the actual cause of a special attack of Mental Disease.

Before commencing to discuss and dwell upon these three points in detail, I may briefly state the basis upon which I venture to express my ideas and conclusions.

The facts elucidated in the accompanying tables have been obtained from an examination into the personal and hereditary history of one hundred consecutive cases. For convenience, fifty of each sex have been taken, but it so happens that for that number of each sex there has been covered almost the same period of time, and they comprise the admissions into the higher rate department of the Crichton Royal Institution for a period extending to well over two years. In nearly all the cases, the history has been obtained by myself, and by personal interviews with relatives when possible. As in many cases this was impossible, my information was obtained in answer to written questions, bearing directly on the points upon which I desired information.

Passing now to the first point which I wish to consider in detail, viz., "The importance of and the position held by Heredity in Mental Diseases," I would at once preface my remarks with the statement that, one animal begets its like and its like only. From this quite unmistakable and incontestable physiological law, we are forced to believe that 
individuals or animals transmit to posterity all the traits that characterise the species to which they belong. Although, in this paper I am trying to bring out the importance of Heredity in Disease, I feel certain that its significance can only be realised if the ordinary physiological law of inheritance be accepted and believed in. If it were not through Heredity where would we, for example, obtain our instinct-the most remarkable and obscure faculty underlying all animal life, and probably the basis upon which a character such as we observe it in the full-grown individual, is built? Apart from instinct, we find that certain families possess or present certain qualities or aptitudes. For example, through some families we find running perhaps for several generations a mathematical, scientific, musical, or artistic temperament, to say nothing of business integrities, truthfulness, and temperance, whilst, on the other hand, one finds in the same way such conditions as drunkenness, dishonesty, untruthfulness, and even bad spelling passing from one generation to another. At every corner, however, we are beset with difficulties, for, although most people would be ready to recognise the occurrence of such qualities and characteristics as I have mentioned, they would be equally ready to explain their presence as being for the most part due to environment and example.

Be it what it may, what I wish first of all to lay stress upon is, that if any given person can transmit his like to an offspring-which is a physiological fact beyond dispute-surely he must also transmit his like in some form, even when that like is an unstable nervous system. What form that like will take must, of course, be greatly modified by environment and by all the numerous unfavourable and antagonistic external circumstances and agents to which we as human beings are subjected.

This being so it is at once apparent that my first two headings, viz., (1) the part played by Heredity, and (2) the significance of the so-called neuro-insane constitution, are scarcely capable of distinct differentiation, for, in my last paragraph I indirectly laid stress upon the inheritance of a predisposition, the significance of which I shall discuss more fully later on.

Coming now without further theorising to the facts which $I$ have elicited from the examination of one hundred consecutive cases, I find that in 55 per cent., 27 males and 28 females, there was a history of insanity or well marked neurosis in the direct ancestors, i.e., father, mother, and grand-parents. Although this is certainly not a large number, still, it comprises more than half of the cases, and one has to consider, of course, the few cases in which reliable information was impossible, and also in those about whom no information at all could be obtained. No attempt has been made to accurately classify or diagnose the exact nature of the mental illness in those near parents, for in a considerable number all the information granted was, e.g., that a father or mother "had been insane." Moreover, I do not think that it is of such infinite importance to try and prove that a parent and child suffered from identically the same form of mental disease; sufficient be it to prove that there was handed down to the offspring such an intensely unstable nervous system that it had at one time culminated in an attack of insanity-an actual attack of insanity being presumably the acme of unstable nerve cells. In more than half of the cases examined then, there 
was a hereditary history of mental disease, and surely even this percentage should be sufficient to make one stagger and dread with fear the begetting of an offspring to those who have at some time in their life been affected mentally.

Having seen then that in $\mathbf{5 5}$ per cent. of the cases there was in the father, mother, or grand-parents distinct evidence of insanity, or of a marked neurosis-which I think is almost of equal importance if it be specially pronounced-the next point that would occur to one is, which parent exerts the stronger influence? Is inheritance stronger from the mother or from the father? Most people believe that the maternal heredity is the stronger, but I must say I do not think that this is at all certain. I am inclined to believe that the maternal heredity is stronger in the case of the female offspring, and the paternal in the case of the male. I am not aware, however, that there are on this point any convincing statistics one way or the other. Certainly one does get terrible and numerous mental "flaws" occurring in a family whose mother was apparently the only weak spot in the geneological tree, but one gets the same bad histories in families where presumably the father alone was the weak member mentally. Both sides can furnish examples in my own series of cases, and many cases could be quoted from other authorities. Dr Bruce ${ }^{2}$ in his work on Clinical Psychiatry quotes a striking case of parental heredity, viz. :- " The father became insane at 70 ; the eldest daughter became melancholic at the climacteric; the second daughter suffered from puerperal mania at 38 ; the third daughter developed adolescent mania at 18 ; and the fourth child, a boy, was born an imbecile-the mother appeared to be a healthy woman."

In my own series of cases, No. 18 (female) furnishes a good example. An extremely neurotic melancholic and rather hypochondriacal father had a family of five, all of whom had had at one time in their life an attack of insanity. Three of the family were sons, and as well as having been at least on one occasion insane, they were all alcoholics, whilst the mother, although she died when young, was apparently quite healthy mentally. Equally striking cases can be quoted as coming from the mother, e.g., No. 14 (male):-The mother was an epileptic, and had five children. Three daughters had had attacks of Melancholia, one son was inclined to be depressed, and the youngest of the family-a son-was an epileptic. It may also be mentioned that one of the mother's sisters had had at least two attacks of Melancholia. Numerous other instances could be quoted from my own series of cases. The hereditary tables in Dr Macpherson's Book (after Möbius and Déjerine) are, indeed, striking as well as most interesting, and show mental defects in whole families, originating in some cases from apparently only one mentally unsound parent.

Coming to my own statistics dealing with the maternal and paternal inheritance, I find that in 34 per cent. (19 males and 15 females) there was a bad heredity through the mother, and if one takes into account maternal grand-parents, the percentage is 42 . On the paternal side the number is also 34 per cent. (17 males and 17 females), whilst taking into account parental grand-parents, it is 42 per cent., the total numbers being identically the same in both cases. As far as my statistics go (although they are certainly limited), there is no proof to show whether the maternal or paternal factor is the more potent. In 22 (or 44 per 
cent.) of the males the minliti heredity was through the father or paternal grandparents, whilst in 19 (or 38 per cent.) it was through the mother. In the females, 23 (or 46 per cent.) showed the morbid heredity through the mother or maternal grandparents, whilst in 20 (or 10 per cent.) it was through the father or paternal grand-parents. The rlifference, therefore, is slight, but what difference there is stems to suggest, as I have already done, that apparently the males sum to take more strongly the Hercdity through the father, and the females through the mother.

It is interesting to note that Darwin, when discussing this point in his book on the Origin of Species, says: "It is a fact of somr importance to us that pcculiarities appearing in the males of our domotic brects are often transmitted either exclusively or in a much greater degree to the males alone."4 Whether or not this is a point of importance I am not prepared to sny, but I fecel certian that an off spuing seldom escapes untouched when both parents are mentally unstable. A mentally healthy father may counteract the unstable qualities of the mother, and my beget mentally healthy children, or a healthy mother may counteract unstalle qualites in the father with the same good result in the offsprirg; but I think it is almost impossible for the offspring to escape where there is a bad Heredity from both parents. It is almost bound to tel] in the orfspring-although in many ways far short of actual mental discase- to make them nourotic subjects, and even if they themselves escape from that appalling disease Insanity, they are so slenderly formed from a mental point of view; they enter the world charged with a mental inheritance so far from stable and perfect; in them there is so little reserve mental stability, that the subsequent generations stand a por chance. As a result of this barl inheritance, they in their turn are apt "to go to the wall," to lireak down mentally, to become alcoholics, degenerates-moral or otherwise-neurotics or neurasthenics, and to be appurent to us as the results of Nature's efforts to exterminate a bald stock, and to show us in a truly ironical way that the fittest survive, whilst the woaklings perish.

Looking more widely into the Hereditary history in my cases, I find 71 per cent. of them came from "bad stock." I mean by this that somewhere in the geneological tree there was a mental flaw--a naw which even if it occurred in collateral or distant relatives was sufficient to strengthen the opinion that one of the progenitors of the person in question had been the unstable thread, that this unstable thread had continued to run into some of the successive generations, and had stealthily asserted itself somewhere in the geneological tree.

In examining only 100 cases, one must be careful to avoid "jumping to conclusions;" dogmatic statements are quite unjustifiable in expressing opinions from facts collected from such a limited field of inquiry. I think, however, that such a percentage as has been obtained is not only striking, but should be a stimulus for further inquiry. The mere fact that in 71 per cent. of people who had been affected mentally there was proved to be. somewhere a hereditary flaw is, indeed, a statement that must give rise to careful thought 
-a statement which cannot be thrown aside lightly, and which must have some bearing upon the production of mental disease.

Having in the preceding remarks tried to point out that a person's parentage is of such importance that it influences to a great extent the character of the individual, I now wish to pass on to the consideration of my second heading, viz., "The importance of the neuroinsane constitution in people the subjects of mental disease." I do not think the importance of such a "constitution" can be overestimated, and, in my opinion, it is the "foundation-stone" of practically all insanities. One can hardly conceive of a healthy, stable-minded individual, born of equally stable-minded parents, being the subject of mental disease; such cases may occur, but I feel certain that they are few. No matter what may be cited as being the true cause of any special form of insanity, be it micro-organism, syphilis, or alcohol, there must be, I think, a special "receptive medium " upon which those factors exert their influence, or bring about their characteristic changes, and this special medium is undoubtedly the neurotic constitution. Many factors, individually or collectively, go to the formation of such a constitution, but, even if one single factor is of outstanding prominence, $I$ think it is sufficient to go a long way in establishing the presence in the individual of an unstable brain, and to make them in one sense neurotic subjects.

The further one gets away from stability of mind, the nearer does one approach the neurotic constitution. Take, for example, a person who exhibits undue nervousness. If that person naturally is always in a state of nervous tension, is that person not more liable to a mental breakdown than the stable-minded individual? Is this undue nervousness not the outward expression of unstable brain cells, and do not unstable brain cells make themselves manifest to us in every form of mental disease?

From our knowledge of the cerebral cortex-slight in reality though it may be-we recognise the clinical manifestations of "storms," presumably among its cells. Are thes manifestations confined only to the mentally unsound mind? In the patient suffering from acute mania they reach their climax, but does the person who exhibits a fit of violent passion not remind us of the person suffering from acute mania inasmuch as for the time being all self-control is gone, all actions are out of gear, the whole brain in fact is in a condition of uncontrollable turmoil? So also the person who is unduly nervous or unduly excitable, in them any slight occurrence may cause, like a match to gunpowder, a sharp explosion, their brain cells are normally in a state of tension-a tension which is far from safe, and which is constantly altering-the results of which are well known to all of us. Nervousness, excitability and extreme passion then are signs of a neurotic constitution; but these are far from all, these are deviations in the "upward" direction so to speak from the normal stable line. So also do we get the "downward" deviations, as evidenced by unnatural gloominess, morbidness, and the tendency to depression.

By some my remarks so far could, I have no doubt, be misinterpreted and misunderstood. I do not wish, nor am I trying, to prove that the person who at a time becomes excitable and depressed, who becomes morbid or loses his temper, is a neurotic. Far from 
that; all those are conditions which probably every human being exhibits from time to time; but what I do wish to point out is that the person who exhibits one or more of those characteristics constantly, is a neurotic, inasmuch as he is removed from the normal line of mental stability. Many people assert that one has no right to call a person "neurotic" without being able to demonstrate in them the physical evidences of such a condition. With this assertion I am inclined to disagree. Undoubtedly one recognises clinically such a condition, based of ten solely upon the general appearance. For example, the thin lipped, delicate, flushed, nervous, and rather apprehensive looking female is a type of neurotic which is to the thoughtful physician quite apparent. It does not need for its confirmation the presence in that patient of the highly arched palate or some other defect in development, although the presence of some such defect would undoubtedly be supporting evidence of the condition.

I consider, then, that any person who constantly exhibits when in his normal self any deviation from stability is a neurotic, is a person of a neuro-insane constitution, and it is that person who is apt to become at some period during their life affected mentally, usually through some adverse external circumstance, no matter whether that circumstance be worry or anxiety, fright or shock, or the "fail-me-never" microbe.

The day has yet to come when special forms of insanity are definitely proved to be due to particular micro-organisms. They may be clemonstrated in certain kinds of cases, but would that special organism cause the same disease if 'injected' into the person with a thoroughly stable brain? Is one to regard Mania, for example, as a disease like diphtheria, cholera, or plague? Surely not! No matter how many organisms are asserted to cause it, one has to remember, I think, that that organism grows only upon a suitable soil.

Many authorities would consider my remarks most unscientific, would accuse me of accepting the causation of insanity without sufficient thought, and would think that my remarks were only relevant had they been expressed several centuries ago. I do not wish, therefore, to be misunderstood; I only wish to lay stress on the neurotic constitution as an important factor, if not an omnipotent one, in the production of mental disease. I have no doubt the time will come when a special organism will be isolated in nearly all kinds of mental disease, but I think the time will never come when the presence of the neuro-insane constitution is overlooked. To do so would, in my opinion, not only be most unscientific, but would be quarrelling with Nature, and putting at defiance her appalling mysteries. Any person who in a true way is trying to solve the hidden mysteries of the causation of mental disease must first of all believe that there is a Nature, that she must be considered along with the wonderful contrivances, suggestions and discoveries of man, in order to unravel the hidden depths.

Turning again to this so-called neuro-insane constitution, I would feel inclined to approach the subject in three ways. Firstly, What exactly does one mean by the term Neuroinsane? Secondly, Is a person born a neurotic, or can the condition be acquired? Thirdly, What direct bearing has the condition on actual mental disease? With reference 
to the first question, What exactly does one mean by the term? This has been already alluded to, and any person is, I think, a neurotic, or of a neuro-insane constitution, who shows in any form pronounced instability or perversity of character. Thus, we have the man who is easily upset, easily excited, who is sometimes in the "seventh heaven," and at times in the depths of despair, the man who is "puffed up" with conceit, so much so that his arrogance almost amounts to a delusion of grandeur, the man who is easily swayed from one course to another, who doubts and hesitates, and has little mind of his own, the man who is solitary and tactiturn, who shuns society, who is uncomfortable in the presence of others, who is naturally of a gloomy, retiring, foreboding, and ultra-religious disposition. Such are but a few examples of what, when carried to extreme, or when persistently present, must be regarded as unnatural qualities, and which betoken anything but a sound and equally balanced nervous system. In a great number of my cases, one or other of these points were outstanding features of the patient's natural disposition. Moreover, I include as well, and consider also of the strongest evidence of this neurotic temperament, any person who has had a previous attack of insanity. Is not this the acme of instability?

Again, is not the alcoholic to be ranked in the same category? Doubtless, a few cases of alcoholism can be attributed solely to force of example, but even in those one must consider the brain cells of the person upon whom the example exerts its influence. Several people may be thrown open to the same examples and temptations, and yet it is probably only the minority that succumb, and is this not on account of the different susceptability or instability of those brains in question? As Féré very aptly puts it, "To become an alcoholic one must be alcoholisable."/5

With reference to the second point. Is one born a neurotic or can the condition be acquired? There is little doubt, I think, but that both conditions may occur. A person may be born neurotic and remain so throughout his life, and there is also, I think, little doubt that it is in this respect that heredity is of such importance. Actual kinds of mental disease are not as a rule transmitted in the same form from the parent to the offspring, although such cases, of course, do very frequently occur. Thus a mother who has had an attack of melancholia may beget a child who also may suffer from melancholia, but it is much more likely that that melancholic mother passes on to her offspring an intensely unstable nervous system-a nervous system which at some future period is apt to give way, and its owner thus to become the subject of a definite attack of insanity. Such a person then is undoubtedly one who has been born with a neuro-insane constitution, the sequela of a bad heredity. It is in this way therefore, I think, that a bad heredity is apt to tell. Although it does not follow that the offspring of a mentally affected parent will become insane, there is every likelihood that that offspring will be unfortunate enough to be possessed of the neuro-insane constitution.

As well as being born in the individual, this constitution can, I think, be acquired. A person may be born and may appear to all intents and purposes quite stable mentally, and further may be descended from parents who in no way were affected mentally-nor did they 
show any marked instability of mind-and yet, that person becomes insane. How does this occur? Where is the suitable soil to be found in this case? The hereditary history is carefully investigated and yet no trace of even nervousness can be found. It is such cases that are apt to overthrow the importance of heredity, and make one feel inclined to think that after all too much importance is attached to it. Still, I hold that this special individual must be of the neuro-insane constitution, in order to allow of his mental breakdown, and, as a matter of fact, one finds if one enquires carefully enough, that the condition has been acquired. The person starts life like his neighbour, with a sound evenly balanced brain; he is, perhaps, in later years exposed to severe strain, his work-business or professional-demands excessive care and thought, and he is subjected to an undue amount of wear and tear. Through stress of business he neglects Nature's laws, he becomes careless about his mode of living, neglects to care sufficiently for his body, is careless about his meals, shuns exercise and recreation, "burns the candle at both ends," all for the sake of his work. His only thought is for his work, and finally he breaks down in health. He is now no longer the same person; what would not have worried him before does so now, what before was natural manly anxiety becomes restless uneasiness, perhaps, even actual depression; he commences to lose interest in things, becomes easily annoyed, apprehensive, and perhaps, irritable; he has, in fact, acquired the neuro-insane temperament, and is now on the level with the person who has that temperament naturally-- the gift of a bad heredity. He in his turn is apt to completely break down and to become affected mentally.

In this way therefore we can often account for the sporadic cases of mental disease springing up in an isolated member of a family, much to the surprise of his relatives, who firmly and possibly quite truthfully assert that such a thing as insanity or even nervousness was "never known of in their family."

The recognition of this method of becoming the subject of a neurotic temperament is not, I think, sufficiently realised. It behoves us as doctors to thoroughly recognise and appreciate it; it behoves us to keep it constantly in view, and to be ready at any moment to step in and check its growth before it is too late, and thereby, from our knowledge to bestow a blessing not only to an individual who may be rapidly drifting towards an Asylum, but also to the yet unborn, who, without being asked and quite unconsciously, are thrust into the world with a heredity over which they have had no control, who are therefore forced to begin the cruel race of the "survival of the fittest" at a great disadvantage and probably much crippled mentally.

I have, then, briefly discussed the meaning of the term neuro-insane constitution; we have seen, secondly, that such a condition may be the gift of heredity; that it is an important, if not an almost natural, sequela of a bad inheritance; moreover, I have tried to show that as well as this it may be an acquired condition, a normal person becoming through stress, strain, or adverse circumstances a person of neurotic temperament.

We are left, therefore, with the third question, "What direct bearing has the condition on actual mental disease?" In answering this point there is, I think, little to add to what 
I have already said in discussing the foregoing points. Its bearing on actual mental disease is an important one, so important is it indeed that I question very much if the healthy stable-minded person ever becomes insane. Even if the exciting cause of any definite kind of insanity be ultimately proved to be in that particular case microbic, or if it be definitely proved to be the result of the ravages of syphilis or alcohol or some such poisons, I think we must still look to the original temperament, representing as it must the nidus for suitable growth, destruction, or development. The favourable soil for the occurrence of growth of mental disease is undoubtedly an unstable brain, and this, I think, is a fact of such importance that it can never possibly be overlooked or ignored. To repeat myself, a melancholic mother may beget a melancholic child, but she is much more likely to beget one who has inherited not the same kind of mental disease, but her intensely unstable nervous system, and who as a result of this 'hereditary gift ' is apt to become in time affected mentally through some adverse external or internal exciting cause.

The results of my statistics dealing with this point, viz., the presence of the neuroinsane constitution in the individual are, I think, most striking and even convincing. Out of one hundred cases, I found evidence of this constitution in 93 instances. It was present in 49 out of the 50 males, and in 44 out of the 50 females. When one takes into account that in at least three cases no information on this point could be obtained, and also that in several cases the information granted was extremely scanty and superficial, these results are indeed striking, and allow one, I think, to express with a certain amount of legitimate dogmatism, the belief that the neuro-insane constitution is an important-if not an omnipotent-factor in the production of mental disease.

I wish now to consider briefly my last heading, namely, "The presence of a direct cause of a special attack of Mental Disease."

I would at once state that 84 cases out of the hundred which I investigated showed the presence of a distinct cause. What then is the significance of such a result? A rapid glance through the "causation" column of my hundred cases would not fail to at once strike one most forcibly that such "causes" as are mentioned are only circumstances which are daily occurrences in the life of almost every adult man or woman. Why should business worry, overwork, stress and strain, love affairs, etc., be accused of making a person insane? Why should such occurrences affect people so very differently? I must say I am not inclined to believe that the adult man who has been bestowed with a strong, evenly-balanced mind becomes insane, nor do I think that he becomes the subject of a socalled "nerve breakdown" through overwork. A man who is living an ordinary healthy life, who is taking care of himself, and who of course is thoroughly well physically, does not succumb when subjected to strain or hard work; he does not as a rule become nervous or neurasthenic after an attack of "influenza;" he does not become melancholic because he is a "martyr," or "a rejected lover." No! A man who has a mental breakdown resulting from one or other of those occurrances is pre-eminently the man with the neuroinsane constitution. Given a man with this highly strung neurotic temperament such as I 
have previously alluded to and described, subject him to severe business worry or strain, place him in difficulties financially, expose him to the worry of an unhappy domestic life, and he will break down almost certainly. One must never forget, however, that if anyone be subjected to such adverse circumstances for any length of time he, so to speak, "moves one down." What was before a strong, stable, healthy-minded man is that no longer; he passes into the second grade and becomes the man of neurotic temperament, and it is he who is apt to break down mentally.

In dealing with the history of mental illnesses, relations and friends are, of course, most eager to ascribe a cause to the attack- "influenza," or a "fall when a child," being most frequently suggested at some time during our interview. Although one knows, however, how much importance to attach to statements like those, there can be very little doubt that careful enquiry and sifting of facts will almost invariably detect a direct exciting cause. The man's illness, for example, will date from his subjection to severe business worry. It may follow the sudden loss of money, or it may follow a severe fright. Is it not, perhaps, natural that overwork, worry, or shock should act in this way on a very nervous brain? Take the man who is strenuously and eagerly working to support his family, who is having a struggle "to make ends meet." Would not the receipt of bad news or some financial loss affect him? Would it be unnatural if he became "down in his luck?" Would he be called dull and morbid if for the time being he slunned society, and sought instead the privacy of his own home? Surely not! but if that man be strong mentally, his worry and anxiety will show themselves in a manly way; he will through time throw them off and gradually rise above his temporary misery. If, on the other hand, he has little reserve stability, is naturally gloomy, and of a nervous and morbid nature, his, what was at first quite legitimate anxiety, will slowly drift into a condition of anxiousness and fear; he next becomes depressed, and finally passes into a condition of true melancholia. His suspicious anxiety and fears remain, he has now lost all sense of proportion, cannot control himself, and from this it is easy to picture almost any kind of mental disease. Such is indeed a common story, and one of every-day experience in asylum life.

I maintain, therefore, that in almost every case of insanity occurring in a person of neurotic temperament, one can trace a definite cause as the exciting cause of the mental breakdown. In such a category also one would place the alcoholics. The neurotic man gives way to drinking. Does he drink because he is a neurotic, or has the alcohol caused that special constitution? For both sides something can be said, and certainly there is little doubt but that alcohol may exert and even cause terrible havoc on a so-called neurotic constitution, so much so that in some cases it must almost of necessity be ascribed as the probable cause of a certain mental attack.

Take again the neurotic girl, is it not perhaps natural that the "pangs of unrequited love" may quite unhinge her, but would it unhinge the strong-minded woman, who free from cares and worries spends her life working in the fields? I think not! Again, does the act of childbearing-severe though it may be-unhinge completely the strong-minded 
mother? I question if it ever does, unless she be naturally a nervous, in other words, a neurotic woman. Many examples could be quoted in dealing with this point, but the conclusion drawn from them all is the same, namely, that in almost every neurotic who has become insane there can be traced a definite exciting cause. My own statistics support this statement, for it was present in 84 per cent. of the cases, leaving only 16 per cent. to be accounted for, and amongst whom one has to remember those most interesting and obscure forms of mental disease which begin gradually, progress slowly, and are in reality a slow evolutionary change in the person's character. With a percentage like 84 , one is, I think, justified in drawing reserved conclusions, and, although I maintain that there is an exciting cause in the majority of cases, I fail to see why, for example, adolescence is supposed to cause insanity. Why should a physiological process be accused of such actions? Surely Nature is not so ironical. On the other hand, there can be no doubt that during the period of adolescence there is naturally so much extra strain thrown upon our brain-which at best is a strange as well as a marvellous structure-that if that extra strain occurs in a person of the neurotic temperament, he will at that period break down, probably through some adverse circumstances.

Take again a disease like General Paralysis. No matter what its true cause may be - be it syphilis or microbe-there can be no doubt that even it is more liable to occur in the person the subject of a neurotic temperament, and more, it not infrequently follows some occurrence which one must at all events consider as being a possible exciting cause.

Turning again to my cases, I find that in 84 per cent. (46 males and 38 females) there occurred some circumstance which was said to be an exciting cause. In 43 per cent. of the cases (28 males and 25 females) that cause was overwork and worry, domestic and financial. In 14 per cent. ( 7 males and 7 females) it was fright or shock. In 16 per cent. (12 males and 4 females) it was alcohol, whilst in 11 per cent. other circumstances, as, e.g., marriage and physical illnesses were stated to be causal. In my statistics the small number of those whose mental illness is said to have been attributable to alcohol is rather striking, but as only one hundred cases have been examined, the small proportion may be simply a coincidence. Another point worthy of note is that out of the 50 females there did not occur one case of so-called puerperal insanity, an occurrence certainly pointing to the fact that such a disease is more a disease of the lower classes, occurring mostly in those who have neither the care nor the attention during a period which is fraught with so much danger, anxiety, and suffering.

Without further comment I will leave my last heading. It has been, I know, dealt with very superficially, but it is a question that is open to so many speculative assumptions that further reference to it is unnecessary. To deal with it at all thoroughly one would be bound to consider the presence or absence of an exciting cause in all of the numerous and obscure forms of mental disease, and in this paper that is almost impossible. In making the assumptions and suggestions that I have done, my remarks have behind them a basis of fact, without which, of course, all statements are in the true sense most unscientific. 
Before summarising my results, and expressing more concisely my conclusions, ther is yet one point that I would wish very briefly to refer to, namely, What exactly is the importance of, or what is the significance of, the presence of well marked physical disease in the ancestry?

In examining my own cases, I found that in 40 per cent. of them ( 20 males and 20 females) there was a record of pronounced physical disease in the hereditary history; I say "pronounced" for I included only the graver maladies. Considering that I did not go so carefully into the physical hereditary history, a percentage of 40 is a fairly large one, and would -probably have been greater had a more accurate investigation been made.

At present a great deal of attention is being paid to the simultaneous occurrence of mental and physical symptoms in the insane, but, what is the significance of marked physical disease in the parents or ancestors of an insane person? That it has some significance there can be no doubt, and one frequently sees quoted as occurring side by side among the members of a family several cases of physical disease and insanity. As an example of this, I may mention the following case (No. 29 of my own series):- Patient was the second son of a family of nine; his father died of "senile decay," and his mother died at the age of 70 of "jaundice." The nine consisted of seven brothers (including patient) and two sisters. Five of the seven brothers and one sister died of phthisis. One sister is intensely nervous and eccentric. One brother (the youngest), who had been delicate all his life, died of "disease of the liver." Three of the brothers at least, as well as dying of phthisis, were alcoholics. The remaining brother-the patient in question-became insane at the ags of 58 .

Again, there is not the slightest doubt that such diseases as phthisis, gout, rheumatism, diabetes, etc., are of very frequent occurrence amongst the ancestors of the insane. It is also an acknowledged fact that parents the subjects of those diseases seem to transmit to their offspring a certain predisposition to one or other of these affections. Does not the presence of say, e.g., phthisis, if it be pronounced in the ancestry, point to a certain physical degeneracy, and if this degeneracy be handed on to the offspring, as it almost certainly is, may it not appear in that offspring in a different as well as in the same form, and, is not that different form very frequently a mental instead of a physical illness-a mental illness being in this case the gift of a weak or degenerate inheritance? Is not this, however, one of Nature's ways of exterminating a weak stock, ironical though it may seem? As I am not dealing with the inheritance of physical diseases in this paper, I shall not dwell upon it, but $I$ wish to point out that, whilst there is frequently seen in the ancestors or relatives of insane persons grave physical diseases-diseases the hereditary predisposition to which is undoubted-it is equally common to find that the predisposition to the special disease in question has been passed over, and its place has been taken by a general predisposition to one of the neuroses, or, perhaps, even to actual insanity. As de Fursac says, "All possible evidences of degeneration are observed among the ascendants and collateral relatives of the insane: neuroses, psychoses, organic nervous diseases, defects of 
character and morals (criminality), arthritic manifestations, gout, diabetes," etc. ${ }^{6}$ We are bound therefore, I think, to believe that such a thing as the transformation of a neurosis may occur.

\section{CON CLUS I O N S.}

Having discussed the various points of my subject in detail, it only. remains now in conclusion to briefly recapitulate and summarise the facts which have been elucidated.

1. In the first place $I$ think we are bound to accept as a fact the physiological law of inheritance, namely, that like tends to beget like; no matter what are the theories of heredity, this law, I think, stands unchallenged. If it be a physiological law of inheritance why should not its importance be of almost equal significance when dealing with an unsound, or 'pathological' heredity? Upon the belief in such a possibility all the problems of this most intricate subject-Heredity-are hinged, and hence I wish to lay some stress upon it. Like tends to beget like, even when that like is an unstable nervous system. It is also acknowledged, I think, that although one animal begets its like, and its like only, the qualities or characters of the offspring-originally those of the parent-are gradually altered or transformed by various circumstances usually to the benefit of that offspring, or in order that they may be fitted for "the struggle for existence." Hence also, the person born of unstable or even insane parents, even although he starts life with a bad heredity and therefore at a disadvantage, has a chance that circumstances may be favourable and helpful, and therefore instead of succumbing and "going to the wall," he may be assisted to a higher level. Were it not for this, were it not that Nature after all tends to protect and help the weak, the world would assuredly soon come to a standstill.

2. From an examination of one hundred consecutive cases, I found that there was a hereditary history of insanity or well marked neurosis in 55 per cent. of the direct ancestors (father; mother, and grand-parents). Besides actual mental disease I included those who showed a well marked neurotic tendency, for, I think, the importance of such a condition can hardly be exaggerated, and is in my opinion, if well pronounced, of almost equal significance as an insane heredity.

3. Further, when one includes as well as the direct ancestors the more distant relatives (aunts, uncles, cousins, etc.), I found that out of the hundred cases 71 per cent. had an insane or neurotic heredity. It is extremely difficult to obtain accurate statements as to the percentage of insanity in the ancestors of the mentally unsound. The percentage varies very largely, probably because some observers include as well, when dealing with this point, the presence of a neuropathic heredity; and with this I quite agree, for, as previously mentioned, it is of almost equal significance. Dr Urquhart, in the Morison Lecture for 1907, records the results of various observers, and he says that "the total neuropathic heredity reaches 72 per cent." Dr Hack Tuke calculated the percentage as 20.5 out of 136,478 admissions into English asylums. Dr H. Grainger Stewart reported 49 per cent. out of 901 cases at Dumfries, but he included eccentricity and recognised this particular 
form of want of mental balance as definitely important. Dr Savage recorded 34 per cent. in Bethlem Hospital out of 1072 persons. Dr W. F. Farquharson recorded 30 per cent. out of 3907 admissions to the Cumberland and Westmorland Asylum. In Dr Urquhart's experience, the percentage of insanity alone rose to 48 per cent. ${ }^{7}$

4. When dealing with heredity it is perhaps worthy of note that there seems to be a tendency for the males to take more strongly the herefity through the father, and the females through the mother, but as only fifty cases of each were examined, I do not feel justified in making any dogmatic statement upon this point; it is an interesting point, however, accurate facts about which would repay a careful and thorough investigation.

5. The next point that I wish to lay stress upon, and that very strongly, is the presence of the neuro-insane constitution in the individual the subject of mental clisease, and in my hundred cases $I$ found evidence of it in 93 instances. What exactly constituted this socalled neuro-insane constitution I fully described elsewhere.

6. I pointed out also that this neuro-insane constitution, besides being in most cases the gift of a bad heredity, was a condition which could be acquired, through adverse circumstances, etc. The fact that the condition can be an acquired one is, in my opinion, not sufficiently realised, especially as I think there can be little doubt that the presence of this neuro-insane constitution is the basis upon which nearly all mental illnesses develop.

7. Given a person with a bad heredity, the results of which are in all likelihood that that person has been born a neurotic; or, even if the neurotic temperament be an acquired one, then, I think, that in order to bring about or precipitate a mental attack, there must be some special cause or causes. What those are it is difficult to accurately state, but usually adverse circumstances, business or clomestic worry, love affairs, alcohol, syphilis, or even microbic infection are sufficient, individually or collectively, to precipitate a mental attack in the person with an unsound brain. I found that in 84 per cent. of my cases there was a distinct cause attributable to their mental attack. In 43 per cent. it was overwork and worry, domestic and financial. In 14 per cent. it was fright or shock. In 11 per cent. it was such circumstances as marriage, physical illnesses, etc., whilst in 16 per cent. it was alcohol. If alcohol be stated to be the cause of the mental attack, then the case would be called by many Alcoholic Insanity. The percentage of such cases varies enormously, probably because no two observers classify alike, and it is in many cases difficult to know whether the alcohol causes the insanity or whether it is only a symptom of the insanity. Dr Clouston says, "From 15 to 20 per cent. of the cases of mental disease in both sexes, and about 25 per cent. in the male sex among the wage-earning classes in the cities, may, taking the country through, be put down to alcohol as a cause 'wholly or in part.' ", At the Perth Royal Asylum, Dr Crquhart obtained a percentage of 9.2 out of $\mathbf{5 2 0}$ total admissions, and he also observed that out of 110 alcoholics nearly 43 per cent. were hereditarily predisposed to insanity and nearly 22 per cent. to alcoholism. ${ }^{9}$ Out of my 100 cases $I$ obtained a percentage of 16 , and which $I$ think might be regarded as a fairly true average. 
8. It is worthy of note that amongst my 50 female cases there was not one case of puerperal insanity, pointing evidently to the fact that this form of mental disease is more prevalent in the lower classes. Although Clouston says, "It occurs in ladies with every comfort and attendance as well as among the poor," he also states, "Poverty and want of proper attendance during child-birth and having to get out of bed and to work too soon, I have seen bring it on."10 Judging from what I have seen both in the higher and lower classes, I have no hesitation in saying that it is more frequent among the latter; but the absence of puerperal cases in my series may possibly be explained by the fact that the majority of the female admissions were unmarried.

9. In 40 per cent. of my cases, I found in the ancestry evidences of grave physical disease. The significance of this must be looked upon with great reservation, although that it is of some significance there can be no doubt. It may at all events mean that the parents were in a sense physical degenerates, and that their degeneracy appeared in the offspring as a mental rather than as a physical flaw, and making one believe, as de Fursac says, that "All possible evidences of degeneration are observed among the antecedents and collateral relatives of the insane."

In dealing with any subject which involves a discussion upon heredity, I am well aware of the numerous pitfalls which one has to encounter. It is easy to theorise about, but almost impossible to prove the many obscure laws which govern our inheritance. It is only by a careful recognition of facts which have been accurately obtained from a large field of enquiry that one can hope to strengthen any one theory. The moment we depart from facts we at once embark on dangerous ground, and only too readily do we drift into the field of speculative assumption, making thereby any theorising, to say the least of it, most unscientific.

\section{REFERENCES.}

I. Green's Encyclopedia of Medicine, Vol. IV., p. I73.

2. Bruce, "Clinical Psychiatry," p. 39 .

3. Macpherson, "Mental Affections," pp. 35-39.

4. Darrein, "Origin of Species," p. 10.

5. De Fursac, "Manual of Psychiatry," $p .147$.

6. De Fursac, "Manual of Psychiatry," p. $q$.

7. Dr Urquhart, Morison Lecture, Joum nal of Mental Science, April 1907.

8. Clouston, "Mental Diseases," p. 483.

9. Dr Urquhart, Morison Lecture, Journal of Mental Science, April sgo7.

ro. Clouston, "Mental Diseases," p. 551 . 


\section{Table I.}

Number of Patients in whom there was in the mother, father, or graudparents 1 (direct ancestors) il history of Insanity, or of a very well marked neurotic $\begin{array}{llllllll}\text { temperament, or of excessive alcoholism } & \ldots & \ldots & \ldots & \ldots & \ldots & \ldots\end{array}$

Number of Patients in wliom there was a history of Iusanity, nourotic tempera2 went, or excessive alcoholism in any other relatives, including also those classified in Clause Table showing the number of cisses of Insanity or $\mid \begin{aligned} & \text { Mother ... } \\ & \text { Maternal Grandparents }\end{aligned}$ $3\{$ of well-marked neurotic constitution in the direct $\}$ ancestors of both sexes

$\begin{array}{llll}\cdots & \ldots & \ldots & \end{array}$

Paternal Grandparents

4 Table showing the influence of

Father and Paterual Grandparents Mother and Maternal Grandparents

$\cdots$

5 Number of Patients who in their usual health exhilited signs-mental, 5 physical, or otherwise-of the "neurotic" temperament

-.. $\quad \cdots \quad \cdots$

f Number of Patients in whom a distinct cause is said to be attributable to the

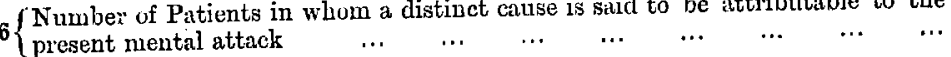
7 Number of Patients in whom alcohol is said to have been the important $7\left\{\begin{array}{llll}\text { causal factor } & \ldots & \ldots & \ldots\end{array}\right.$ $\{$ Number of patients in whom overwork and worry (domestic or financial) is $8\{$ said to have been the inportant causal factor $\quad . . \quad \ldots \quad \ldots, \ldots \ldots$ Number of Patients in whom fright or shock is said to have been the important $\begin{array}{lllll}\cdots & \cdots & \cdots & \cdots\end{array}$ 10 $\{$ Number of Patients in whom other circumstances-marriagre, illnesses (physi(cal), \&c. - are said to have boen causal

Number of Patients in whom there was in the ancestors or descendants some 12 outstandiug physical disease, e.g., Cancer, Phthisis, Rheumatism, Gout, Diabetes, \&c. ... 


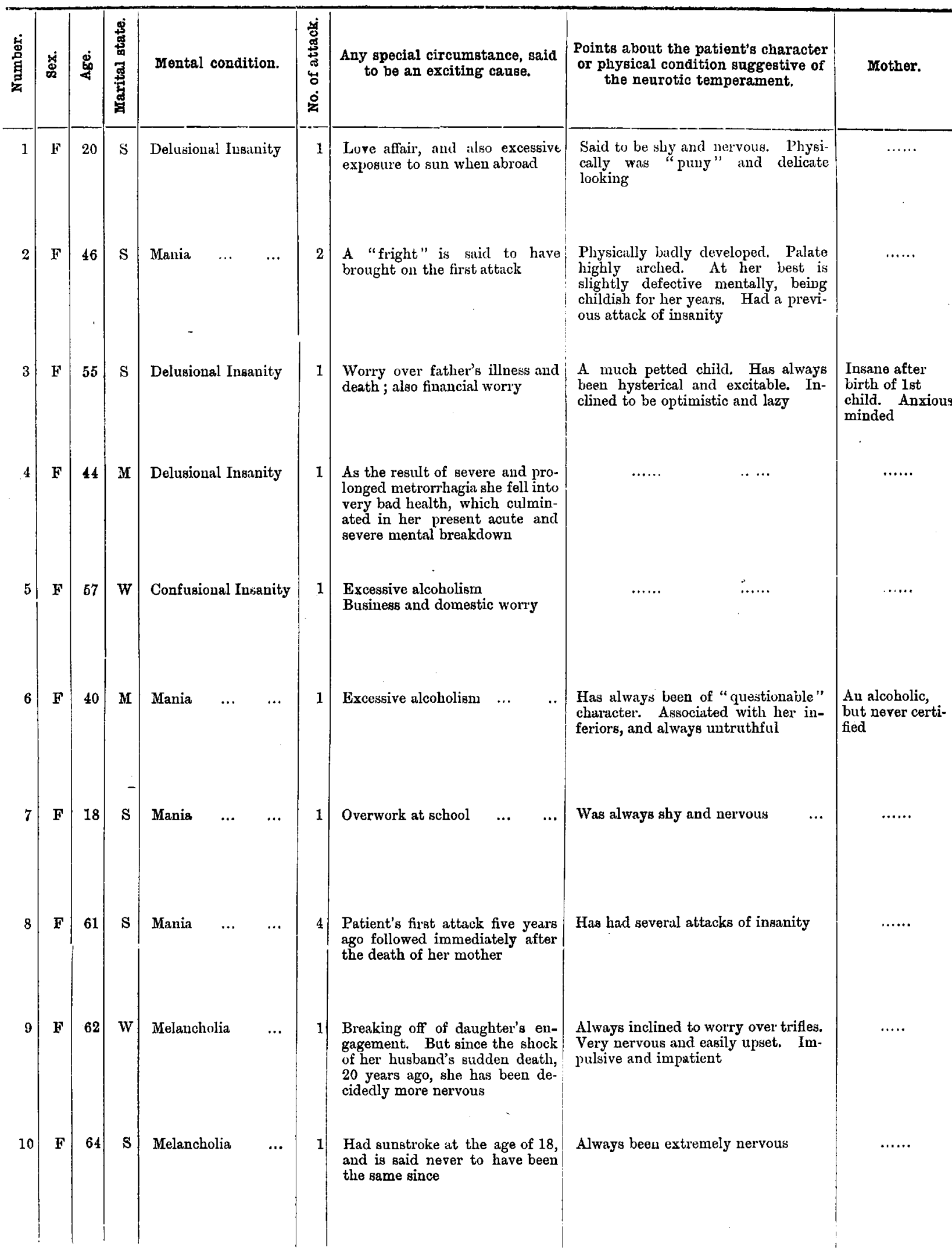




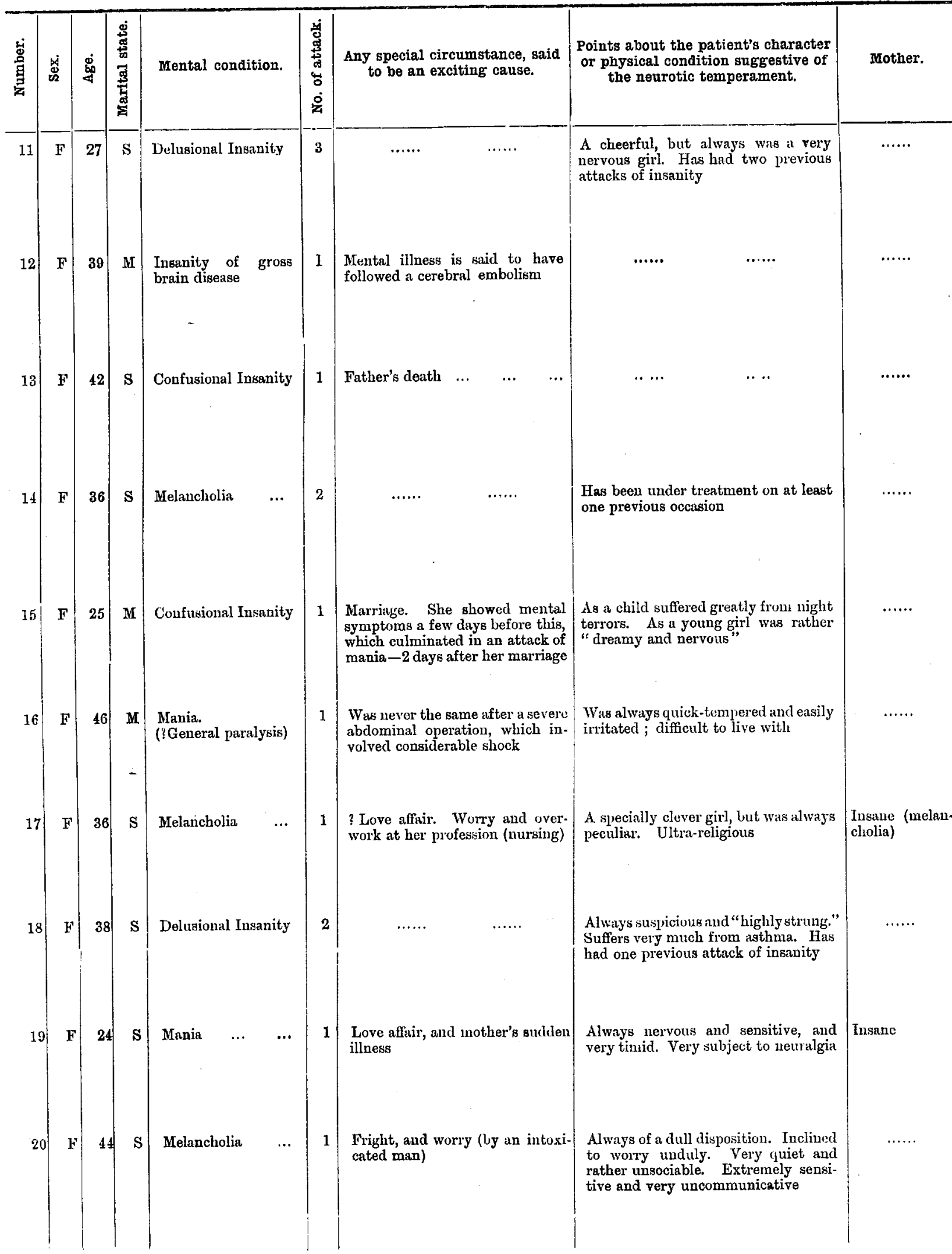




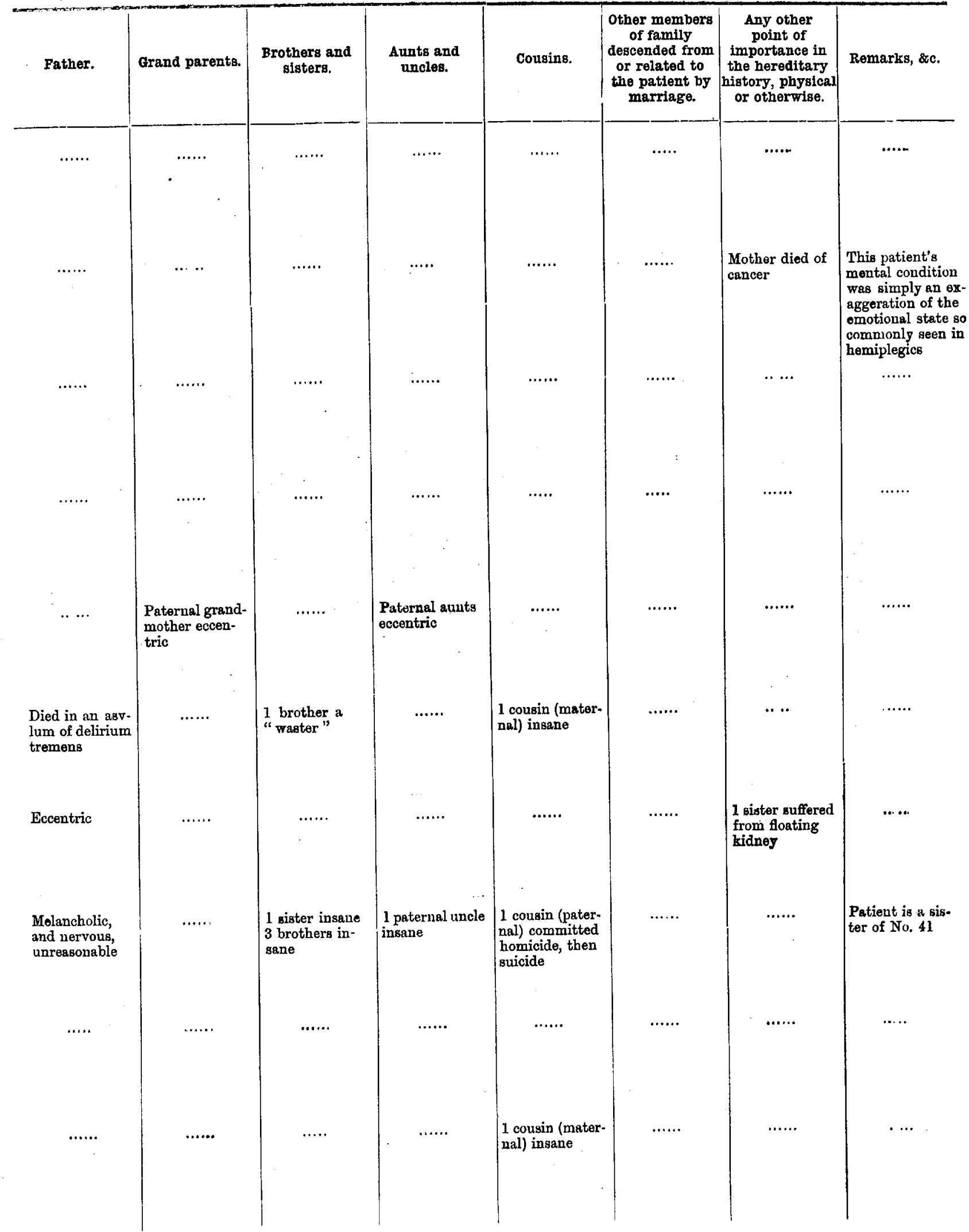




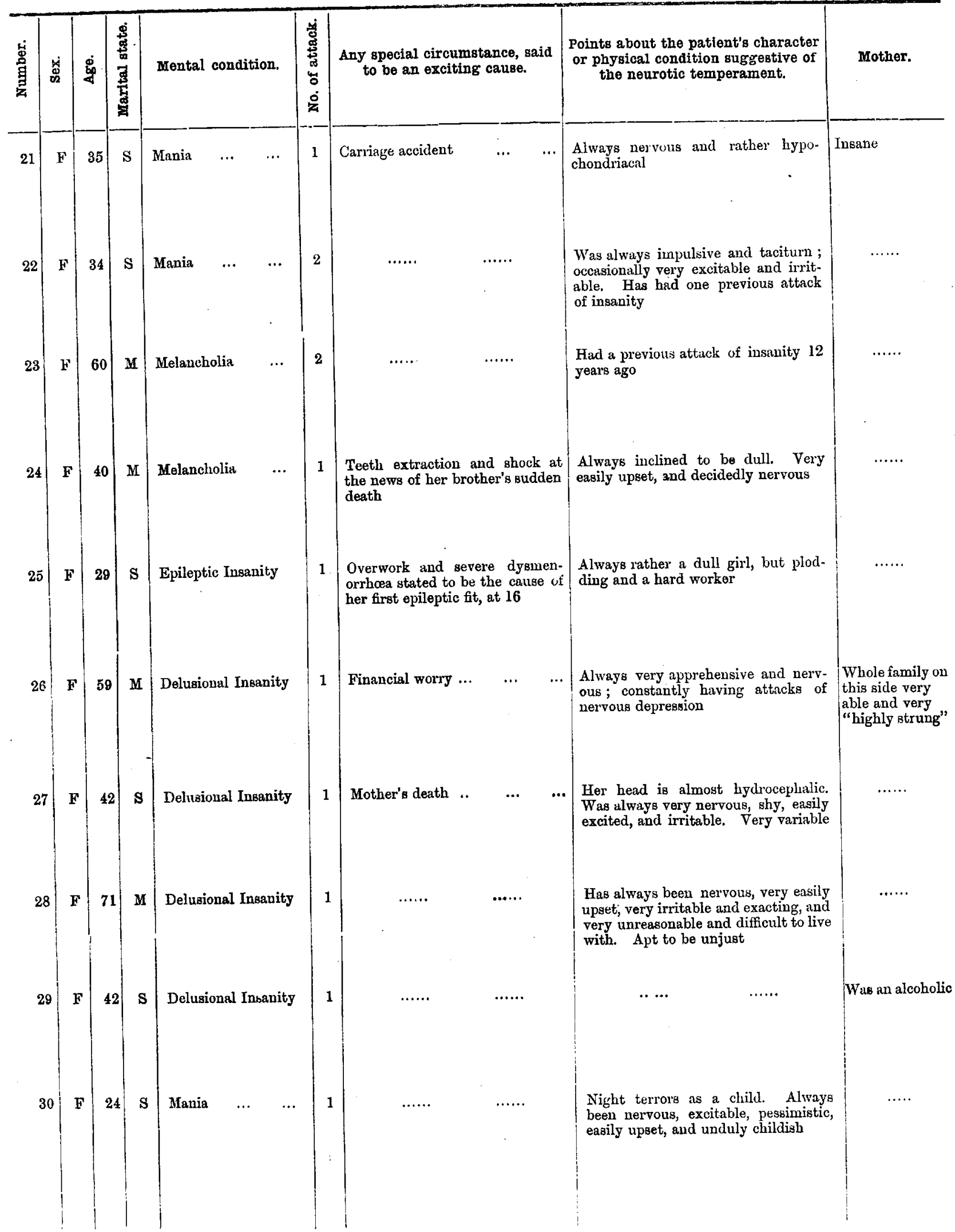




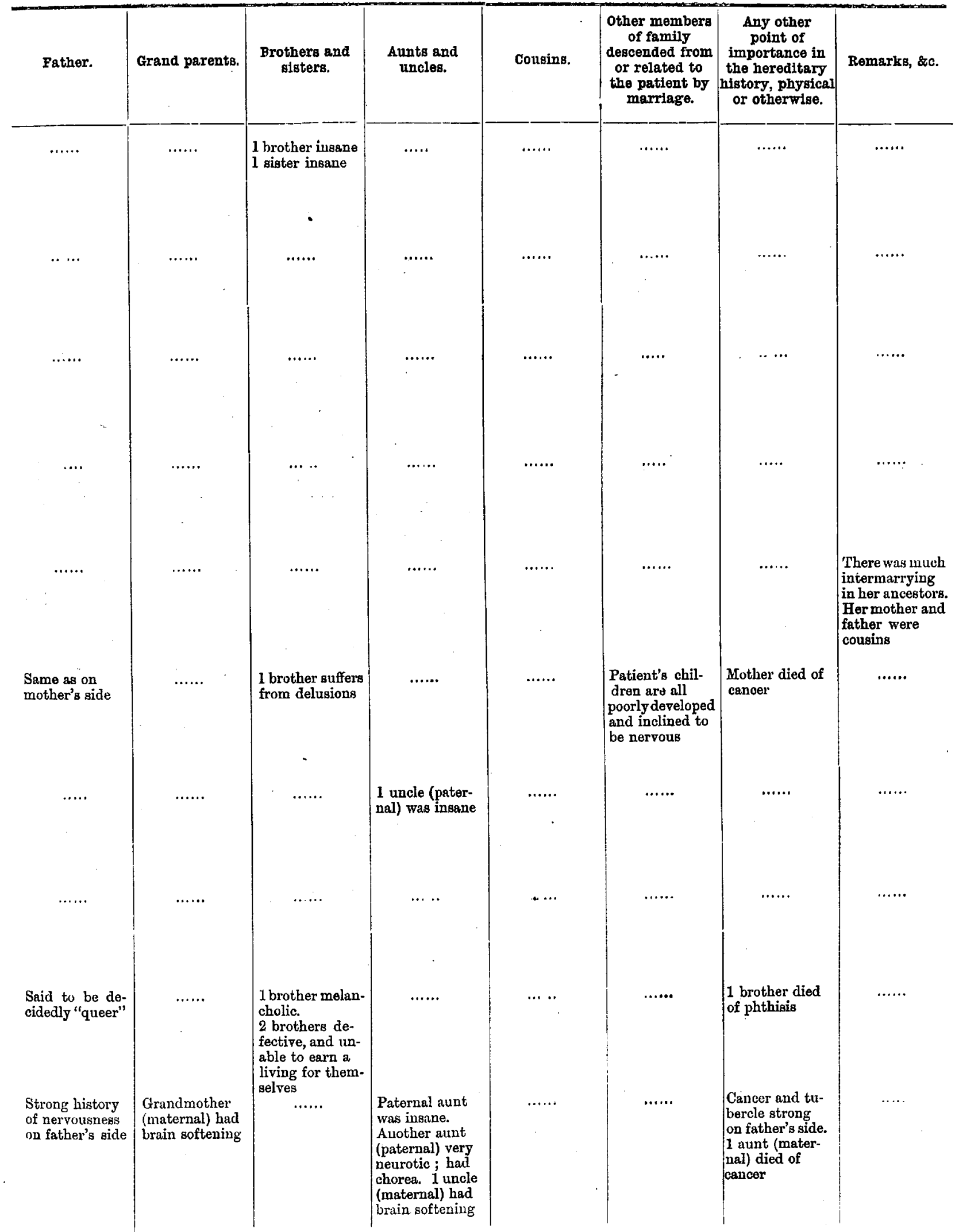




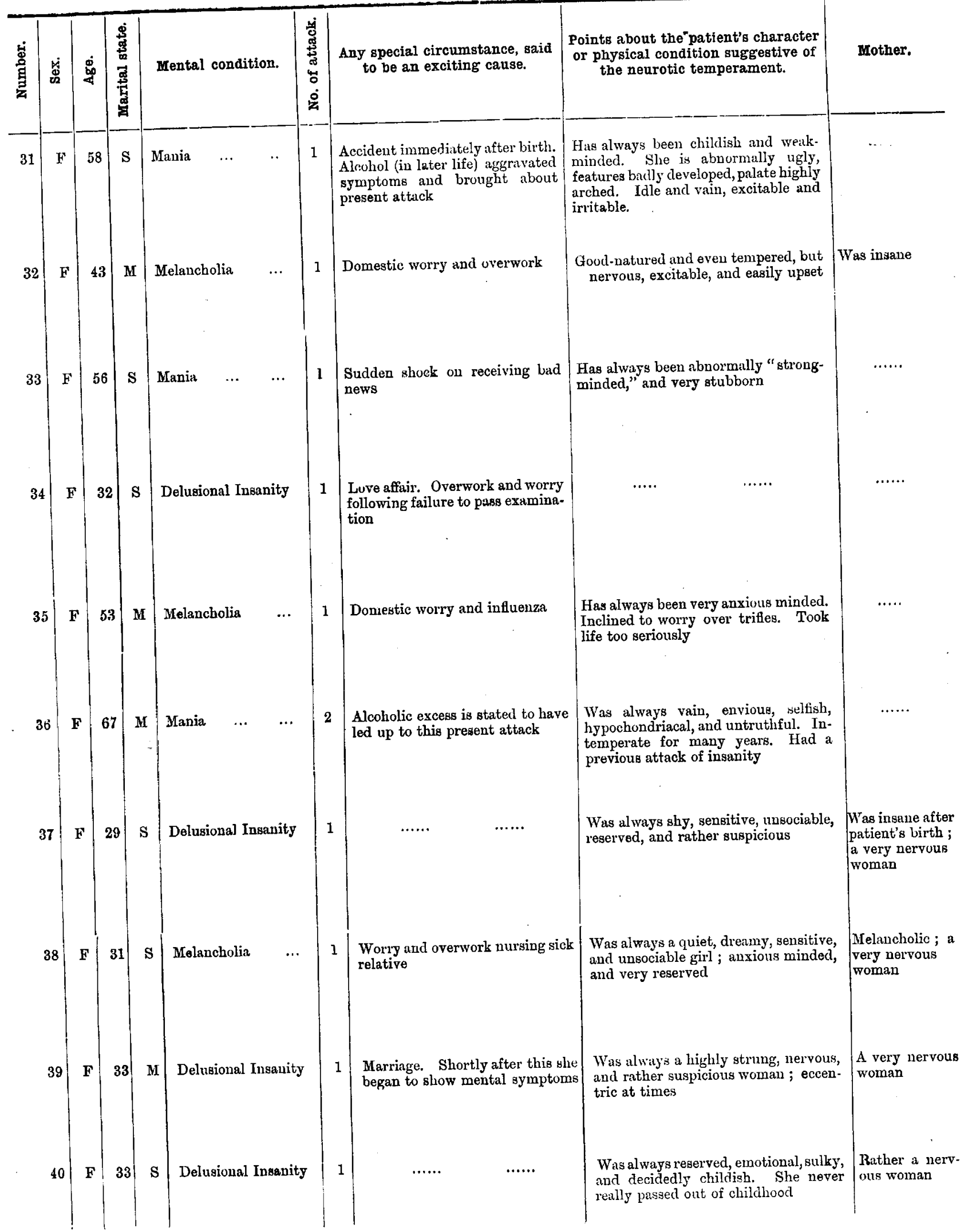




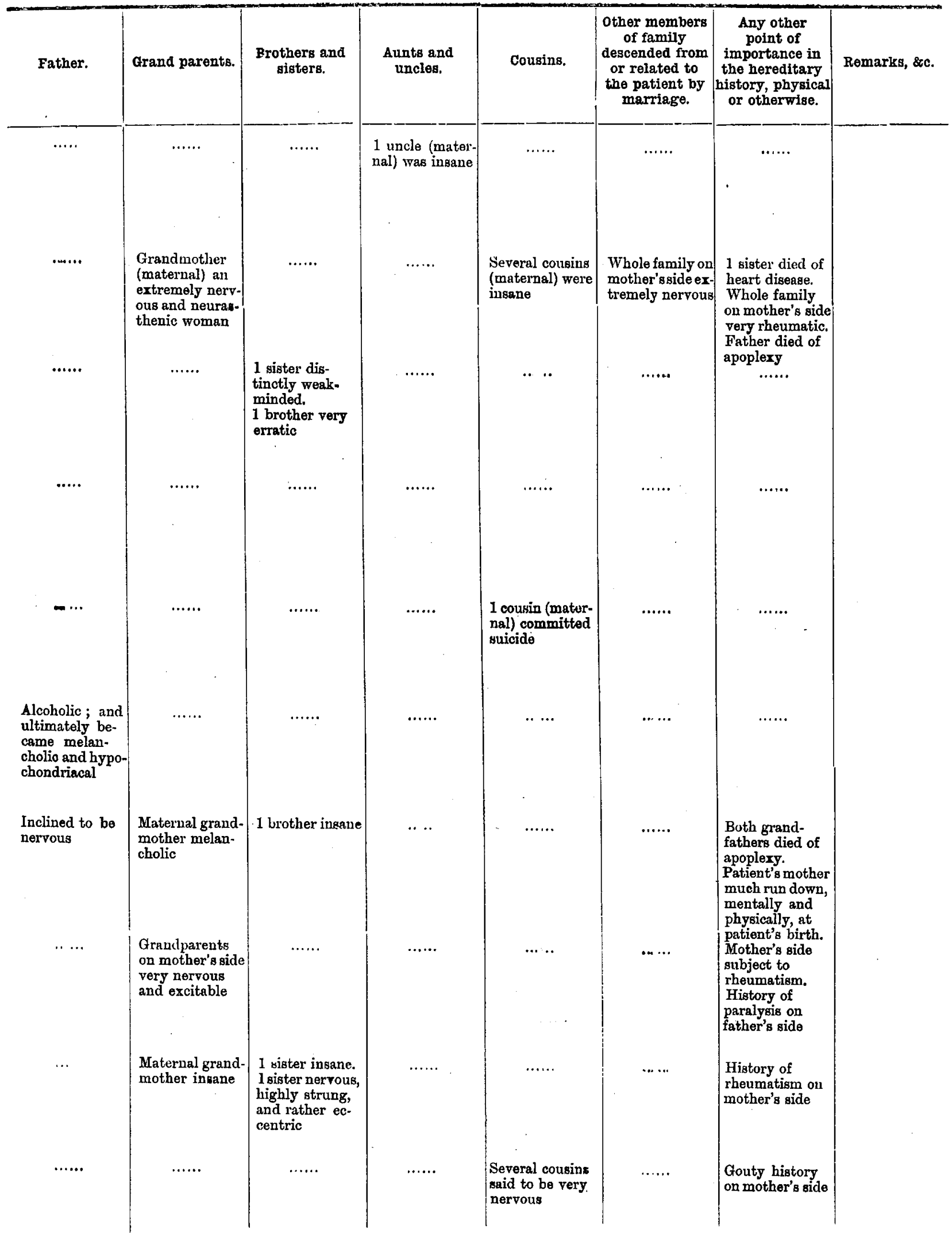




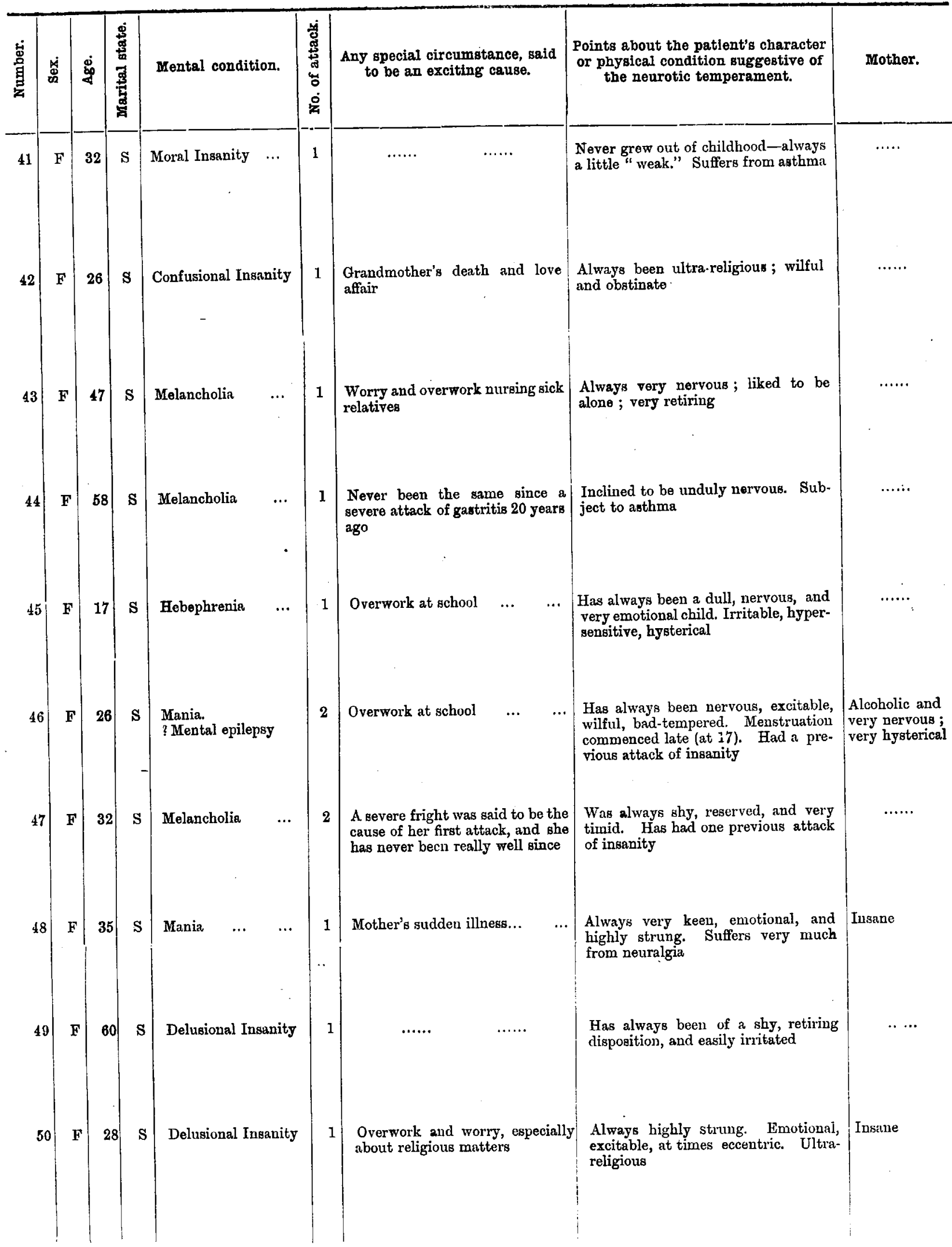




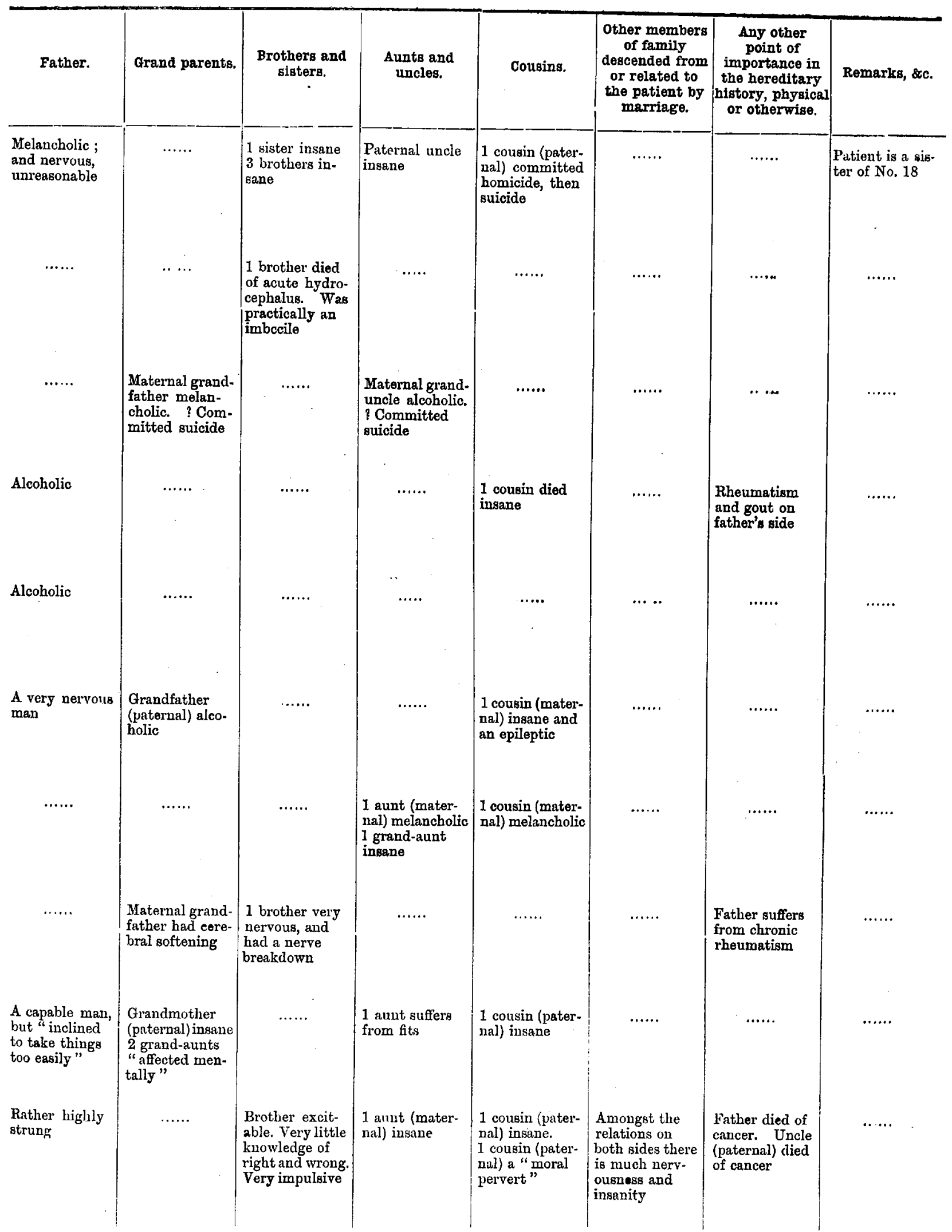




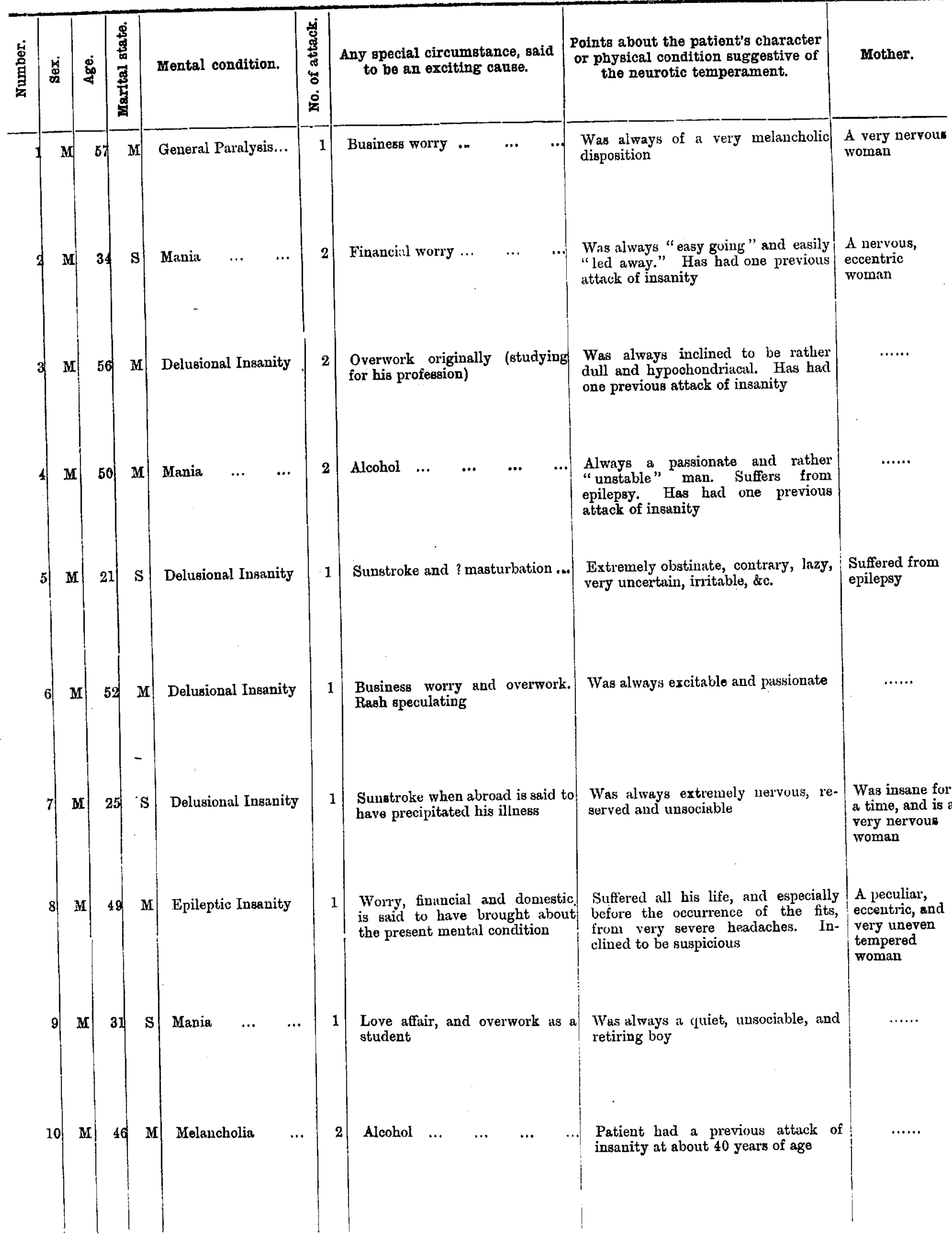




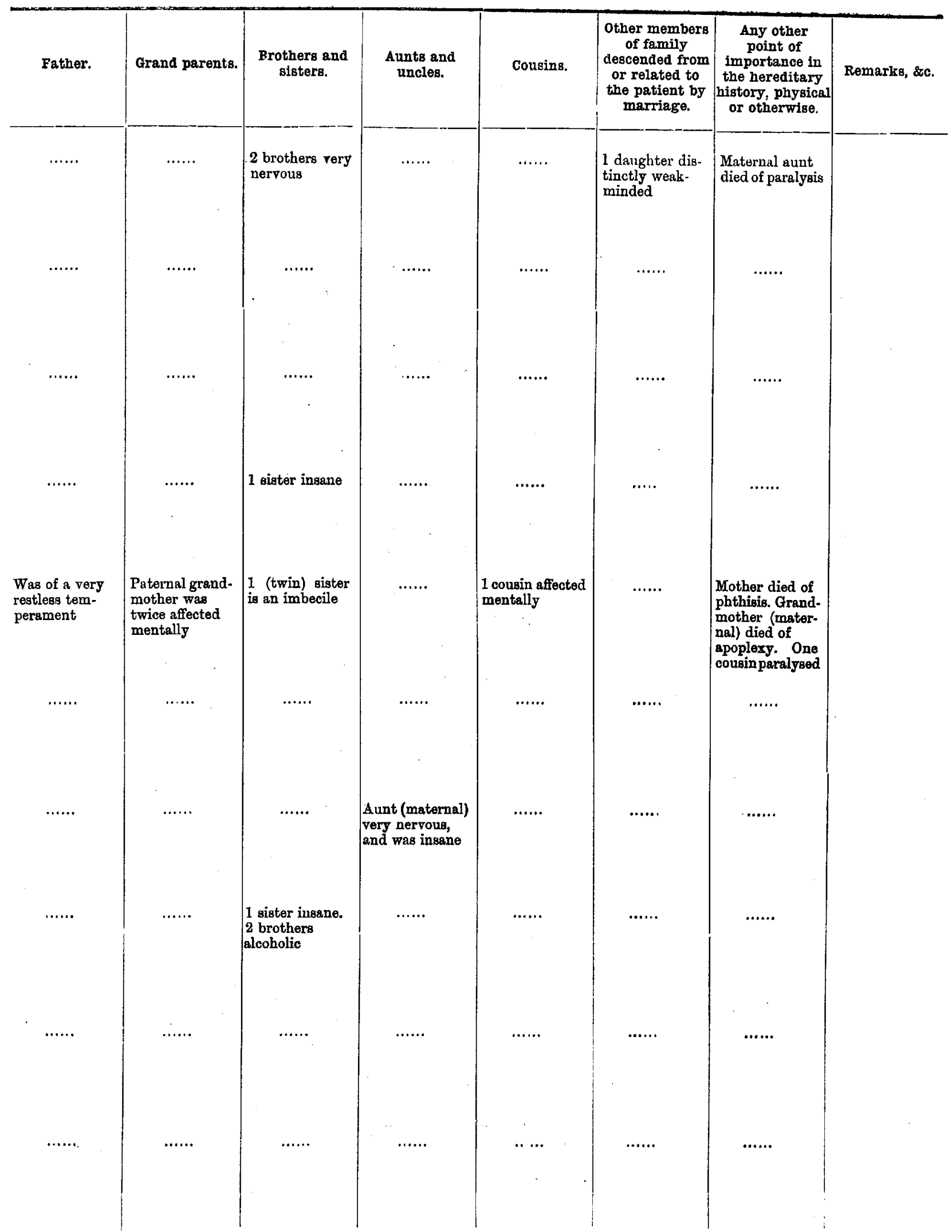









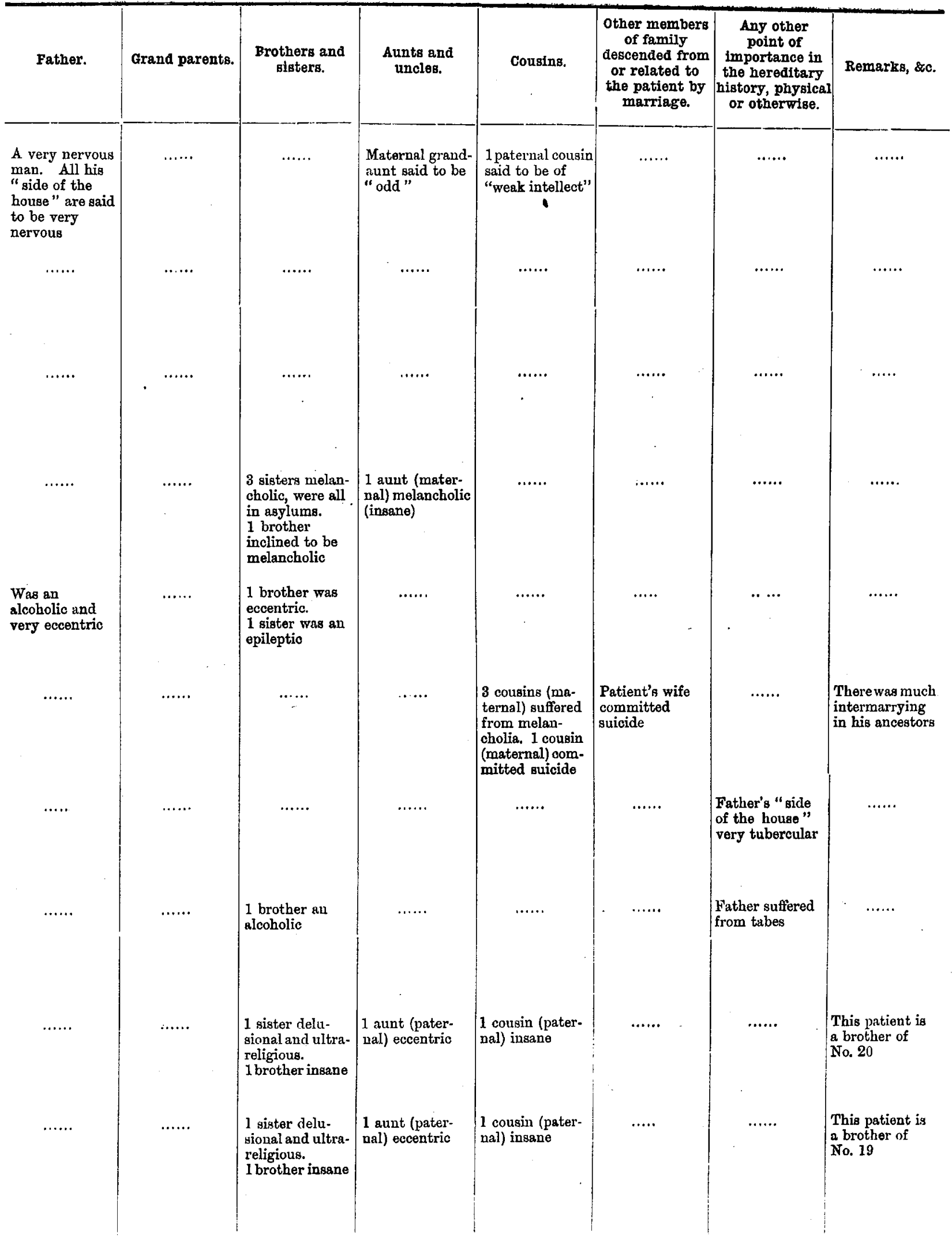




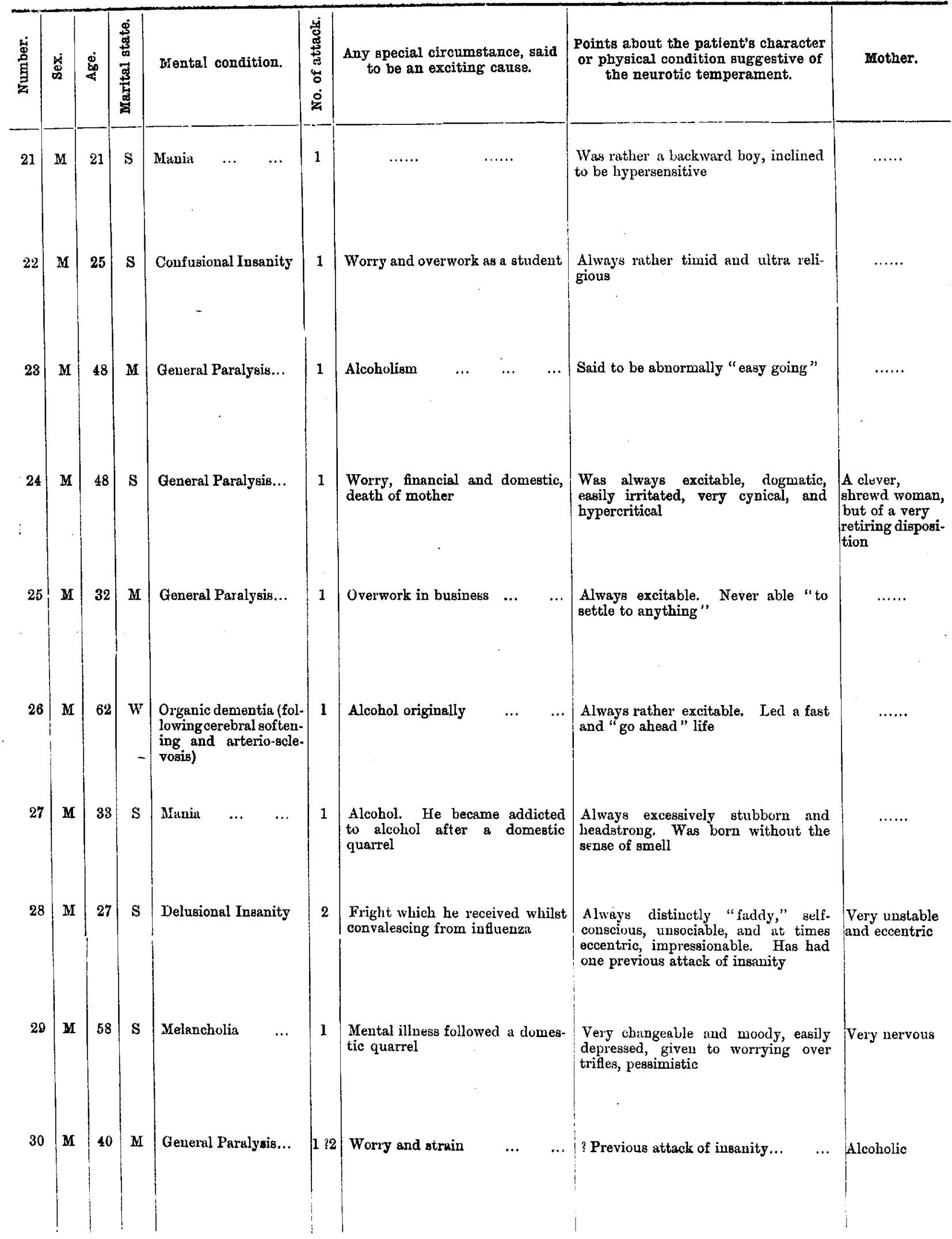




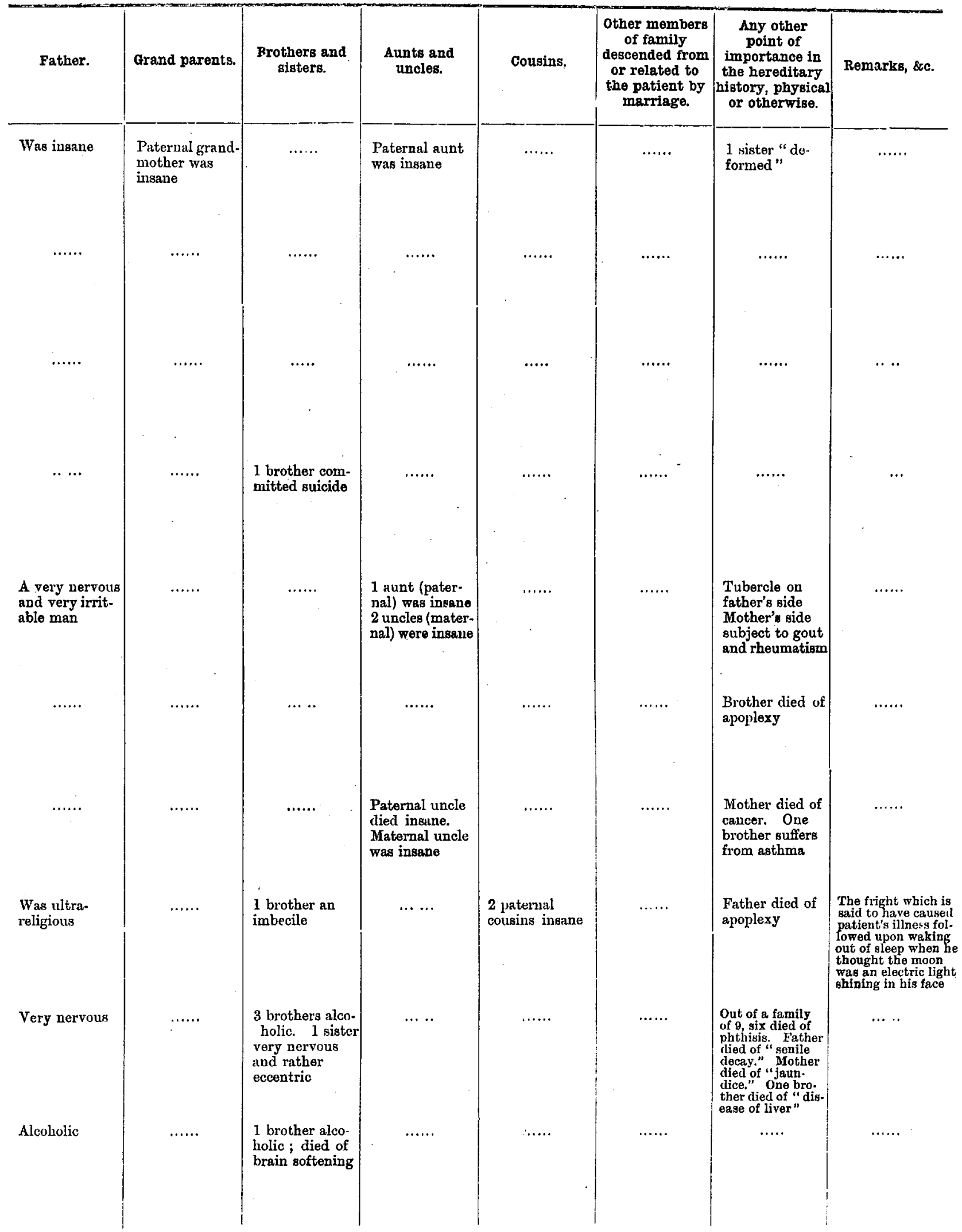




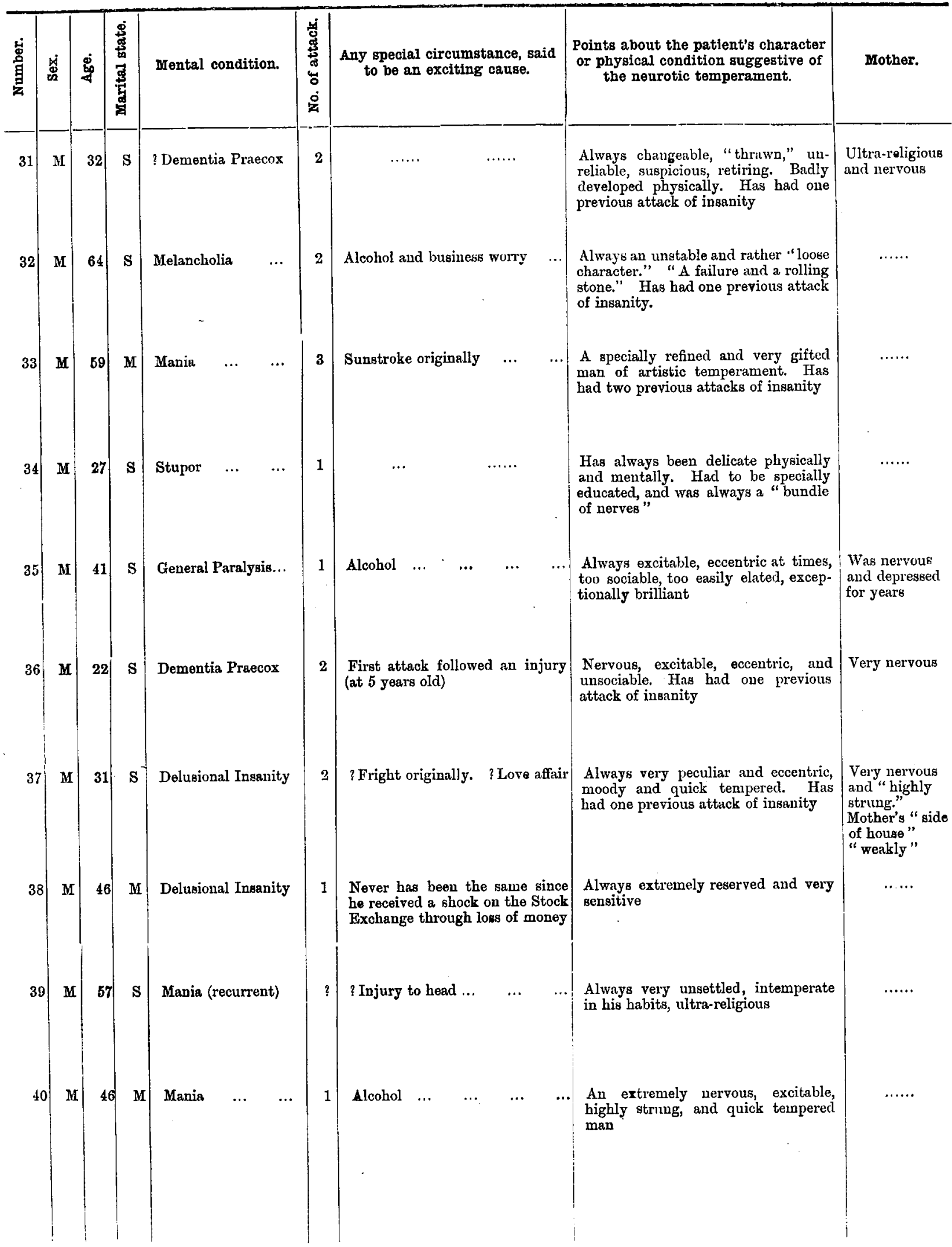




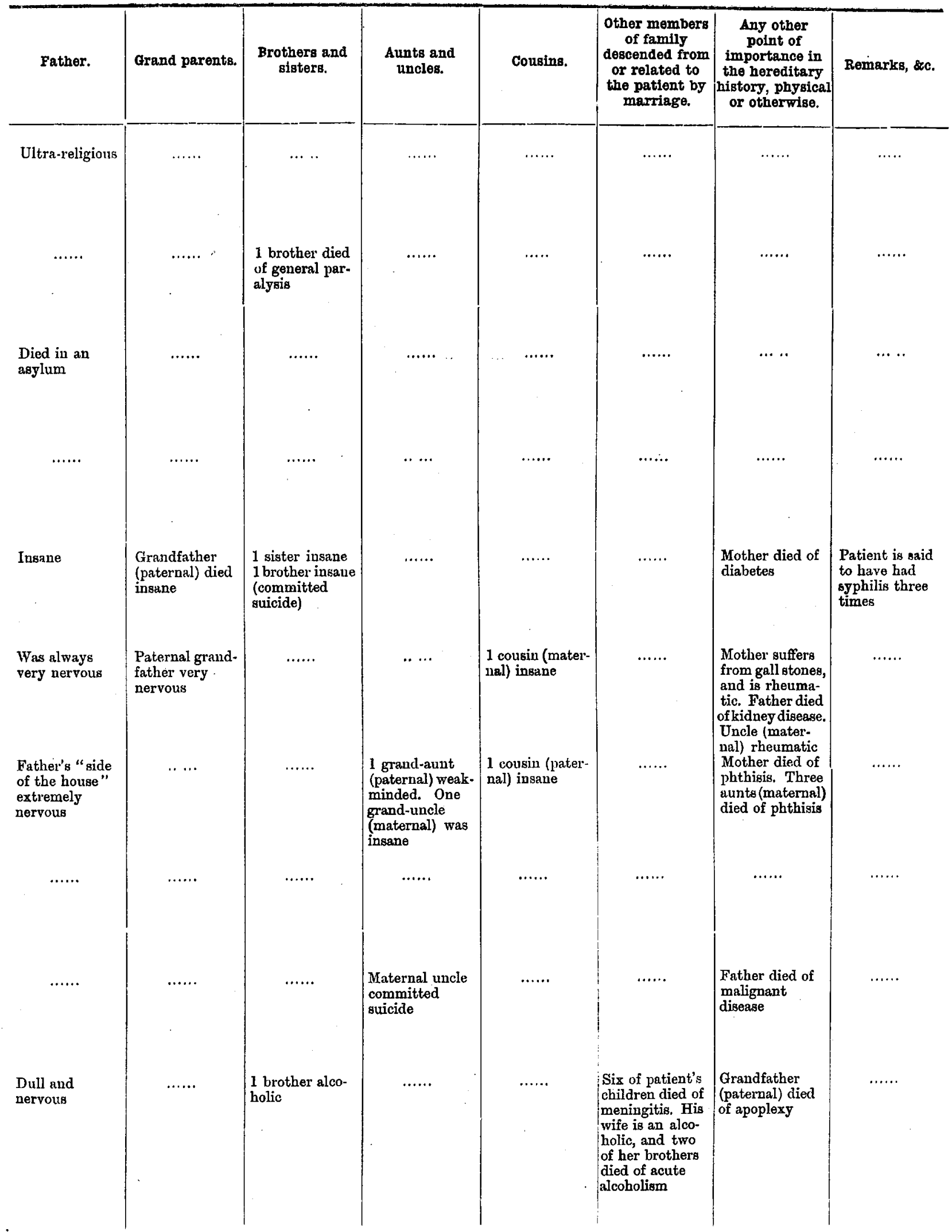




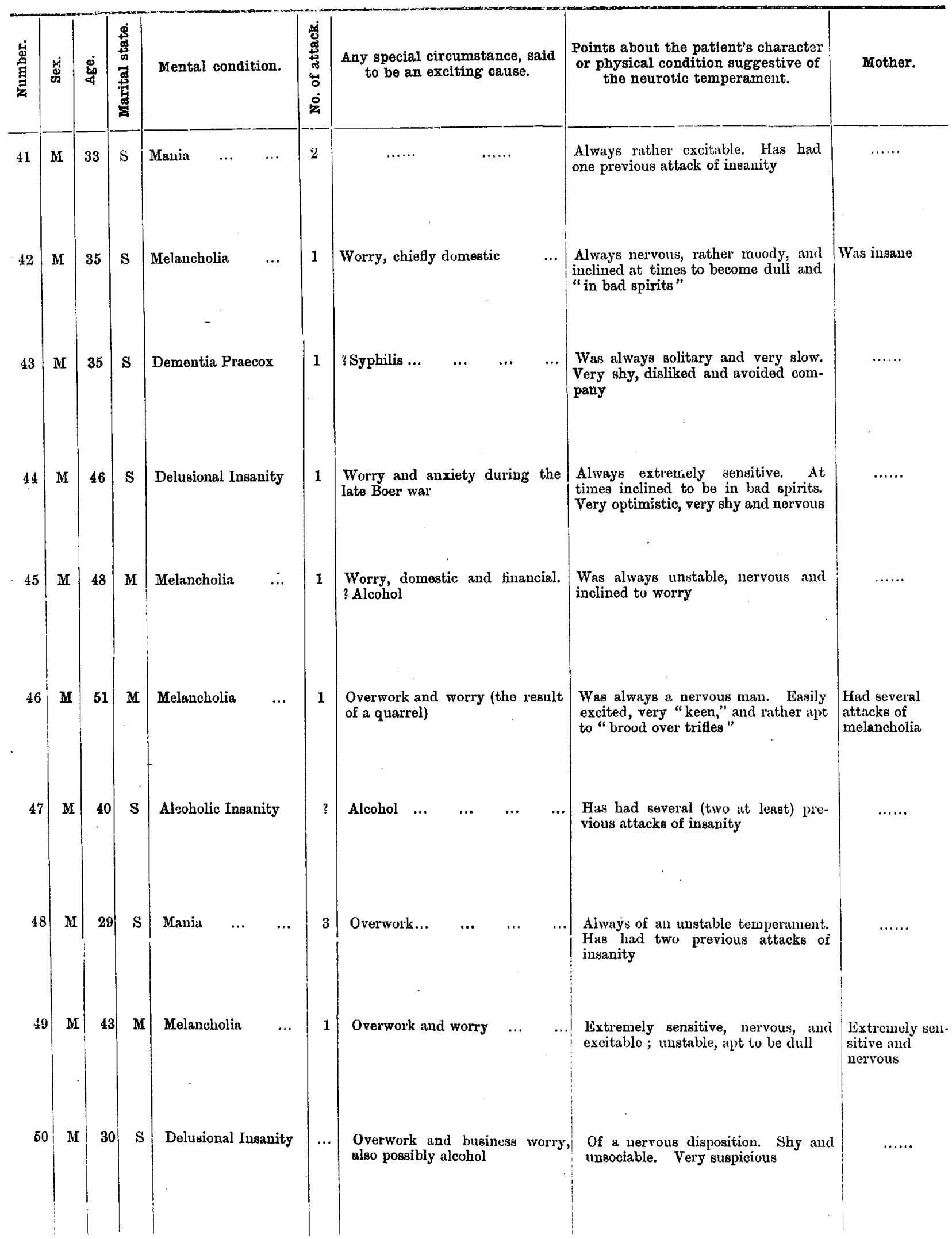




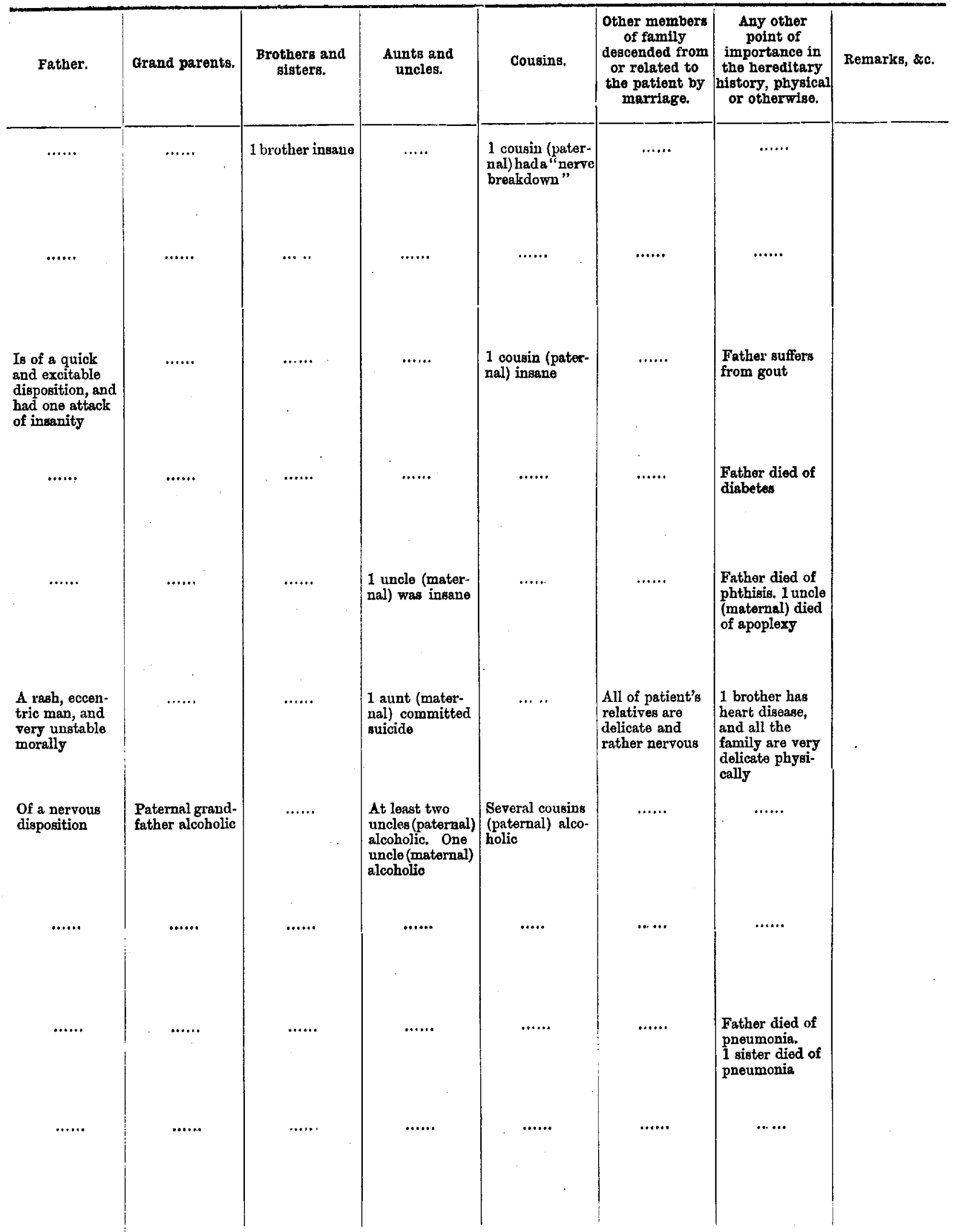

